University of Louisville

ThinkIR: The University of Louisville's Institutional Repository

Electronic Theses and Dissertations

$12-2011$

\title{
Addressing identity/redressing the museum.
}

Sarah Guadalupe Cassidy

University of Louisville

Follow this and additional works at: https://ir.library.louisville.edu/etd

\section{Recommended Citation}

Cassidy, Sarah Guadalupe, "Addressing identity/redressing the museum." (2011). Electronic Theses and Dissertations. Paper 222.

https://doi.org/10.18297/etd/222

This Master's Thesis is brought to you for free and open access by ThinkIR: The University of Louisville's Institutional Repository. It has been accepted for inclusion in Electronic Theses and Dissertations by an authorized administrator of ThinkIR: The University of Louisville's Institutional Repository. This title appears here courtesy of the author, who has retained all other copyrights. For more information, please contact thinkir@louisville.edu. 
ADDRESSING IDENTITY/REDRESSING THE MUSEUM

By

Sarah Guadalupe Cassidy

B.F.A. Milwaukee Institute of Art and Design, 2004

\begin{abstract}
A Thesis
Submitted to the Faculty of the

College of Arts and Sciences of the University of Louisville in Partial Fulfillment of the Requirements

for the Degree of
\end{abstract}

Master of Arts

Department of Fine Arts

University of Louisville

Louisville, KY

December 2011 
ADDRESSING IDENTITY/REDRESSING THE MUSEUM

\author{
By \\ Sarah Guadalupe Cassidy \\ B.F.A. Milwaukee Institute of Art and Design, 2004
}

Thesis Approved on

November 18, 2011

by the following Thesis Committee:

Jdhn Begley, Thesis Director

Dr. Susan Jarosi

Dr. Steven Koven 


\section{DEDICATION}

To space explorers and boot makers,

and their lovers and children, and their children's children, who have found all the love in the universe and delivered it to me.

I am eternally humbled and grateful. 


\section{ACKNOWLEDGEMENTS}

I am absolutely indebted to Suzanne Weaver for her immeasurable guidance and support, as well as her generosity in sharing her knowledge with me over the last two years. I must also thank John Begley, the Director of Galleries at the Hite Art Institute, and the director of the Critical and Curatorial Studies program at the University of Louisville, who facilitated my internship with Suzanne Weaver and made all my successes in the program possible. Thanks are due also to Professor Steven Koven for agreeing to sit on my thesis committee and to Professor Susan Jarosi who is also on my committee and has truly been a mentor to me. I cannot forget Brooke Leeton, Vanessa Johnson, Kaelin Jewell, and Jeff Hipsher for their support and love throughout this whole process. Last but not least, I am so grateful for my mother, whose faith in me has given me the confidence to realize all of my ambitions, and for my father whose long talks and insights exercised my brain throughout my life and made me the thinker I am. 


\section{ABSTRACT \\ ADDRESSING IDENTITY/REDRESSING THE MUSEUM \\ Sarah Guadalupe Cassidy}

December 13, 2011

This thesis paper expands upon the aspects of identity and power explored in the exhibition that I curated, entitled "Being \& Making: Artists Investigating Identity," at the Speed Art Museum. The developments on topics of identity prominent in the United States in the 1980s and 1990s fundamentally changed the creation, exhibition, collection and interpretation of art. These changes related to power investigations originating from artists in marginalized groups. The change affected not just the art itself, but also the function of museums and the role they play in forming identity in contemporary visual practice. As institutions of power, art museums absorb investigations of identity into their operations to sustain a current and relevant position in contemporary culture. This process has caused a paradigm shift in museum management and operations. Feminist theory is a major proponent of this shift and is the key to its continuation into the future.

I will analyze the relationship between the two ideologies: investigations of identity in contemporary art coupled with the new museology. I will conclude with the assertion that feminist theory is the basis of this paradigm shift. The rise into prominence of investigations of identity and the new museology coincided, as they were influenced and propelled by feminism and by the cultural and political climate at the end of the twentieth century and into the new century. I argue that the new museology resulted from 
feminist and poststructuralist investigations of identity and power, as museums struggled with their positions as structures of power in the art world. 


\section{TABLE OF CONTENTS}

ACKNOWLEDGEMENTS




\section{LIST OF FIGURES}

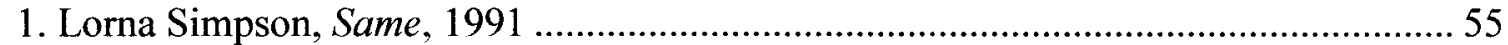

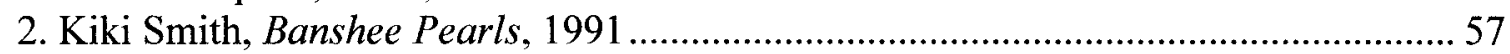

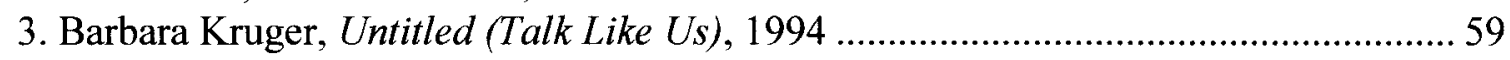

4. Barbara Kruger, Untitled (Think Like Us, 1994 ........................................................ 59

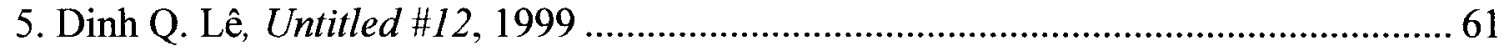

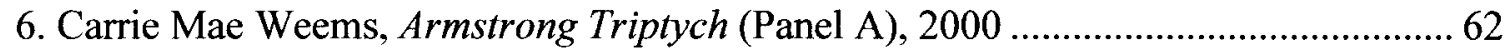

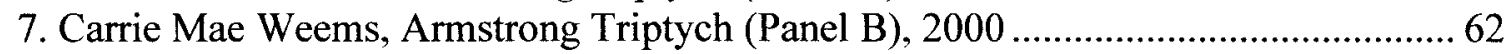

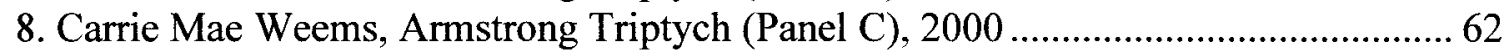

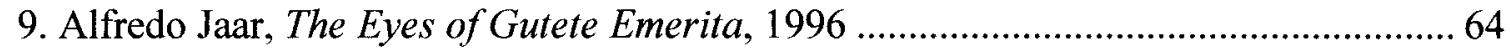

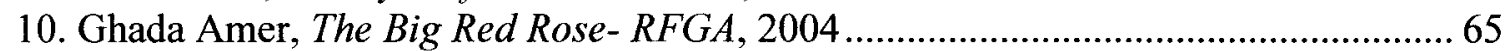

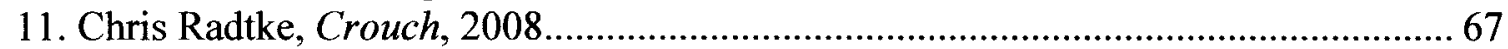

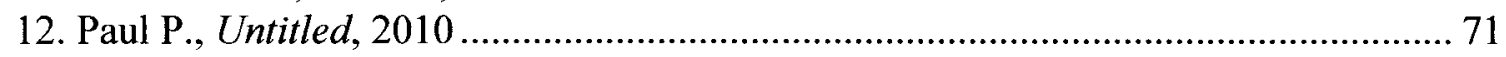

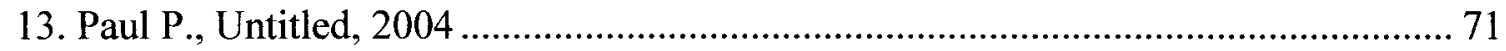

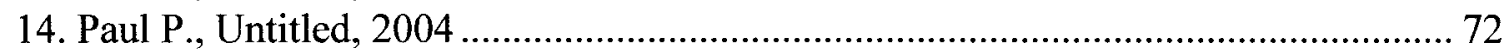

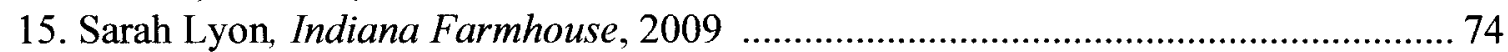

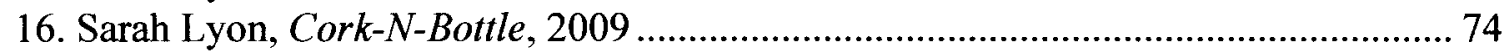

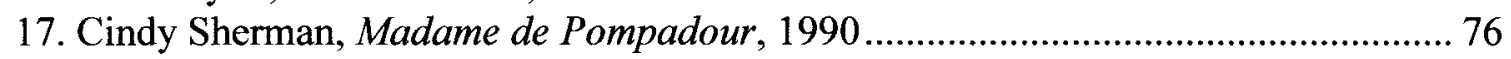




\section{INTRODUCTION}

This thesis began with the exhibition entitled "Being \& Making: Artists Investigating Identity" presented at the Speed Art Museum in Louisville, Kentucky from July 2 through November 6,2011 . The exhibition was the result of my two-year internship with the Speed Art Museum's curator of contemporary art, Suzanne Weaver. I interpreted the work included in the exhibition under themes of identity and power. This portion of the thesis expands upon current discussions of identity and power, and considers the impact these notions have on contemporary curating, art making, exhibiting, collecting, interpreting, and establishing institutional identity. Developments in these fields of inquiry led to the collection of the work in the exhibition, and presumably resulted in the Speed Art Museum's interest in approving my proposal for the exhibition.

Developments regarding the topic of identity in the United States in the last quarter of the twentieth century fundamentally changed the creation, exhibition, collection, and interpretation of art. These changes affected not just the art itself, but the function of museums as well. As presented in the exhibition's main text, the question is not only what comprises identity but also who. The "who" in this paper focuses on art museums, and the role they play in forming identity in contemporary visual practice. Art museums, as institutions of power, have absorbed investigations of identity into their practice in an attempt to sustain a current and relevant position in culture.

A paradigm shift in curating, and museum management and administration occurred in the 1980 s and 1990s. The paradigm shift is often referred to as the new 
museology, a political critique of the museum as an institution and ideology "situated in the colonial and imperial histories of modernity's constructions of nations, races, and genders." This critique shifted focus away from the canonical object and onto the institution itself, the role of the spectator, and the politics of display. In the midst of these investigations, museums recognized the need to move away from an insular focus on research and acquisitions to a more visitor centered approach that analyzed, evaluated, and responded to its public. The late Stephen Weil, a lawyer-turned museum administrator and former deputy director of the Smithsonian Institution's Hirshhorn Museum and Sculpture Garden, is often credited with "making museums matter" by shifting museum ideology from "being about something to being for someone."2 The move from inward focus to community focus is a direct response to a history of exclusion and elitism that threatens the downfall of many institutions.

In this thesis, I will analyze the relationship between the two ideologies: investigations of identity in contemporary art coupled with the new museology. I will conclude with the assertion that feminist theory is the basis of this paradigm shift. The rise into prominence of investigations of identity and the new museology coincided, as they were influenced and propelled by feminism and by the cultural and political climate at the end of the twentieth century and into the new century. I argue that the new museology resulted from feminist and poststructuralist investigations of identity and power, as museums struggled with their positions as structures of power in the art world.

\footnotetext{
${ }^{1}$ Griselda Pollock, "Unframing the Modern: Critical Space/Public Possibility," in Museums after modernism: strategies of engagement, eds. Griselda Pollock and Joyce Zemans (Malden, MA: Blackwell, 2007), 1.

${ }^{2}$ Stephen E. Weil, Making Museums Matter (Washington, D.C.: Smithsonian Institution Press, 2002).
} 
The rhetoric of identity discourse allows museums to restructure their focus and redirect their missions to maintain relevance both in their communities and to the artists they collect and exhibit. As part of this effort, museums administer identity-related visitor evaluations in order to understand the needs of their community, and align themselves with the shifting paradigm. Many survey-formatted art museums have made great strides in representing identity and giving agency to their visitors, but these changes are new. Feminist theory informed the major shift behind these changes and will propel it into the future, allowing museums to conceptually restructure the way that they exhibit, interpret, and collect art in order to allow for a more integrated, progressive, and inclusive representation of their communities and the culture in which they operate. 


\section{IDENTITY AND POWER STRUCTURES}

Questions of who we are and what we do, and who determines who we are and what we do, are vital to the development of nations around the world. It is why nations fight wars, enact legislation, and why people participate in their communities. These questions influence every facet of public life. In private life, however, these questions are more immediate and part of every individual's emotional, social, and intellectual development. In post-World War II America there was a focus on self-discovery, mirrored in art movements like Abstract Expressionism where Jungian psychology and existentialist philosophy suggested that individuals were integrated, stable, and unique, with independent actions and "meaningful intentions and a coherent inner psychology."3 Once an individual came to know her true self, she could act purposefully, with clear foresight, and strong vision. Although this theme ran throughout the middle of the twentieth-century, by the 1980 s the focus on the individual as the locus of identity began to dissolve.

Theories of deconstruction and poststructuralism gained attention in the late 1960 s and 1970s, and led to investigations of social structures, which extended to structures of power and identity. The dissolution of the individual as the locus of identity, and the understanding that identity is a fluid construction is central to Being \& Making. Both of these tenets are linked to poststructuralism and have been adopted into feminist discourse, as feminism is chiefly concerned with power structures that inform sexist

\footnotetext{
${ }^{3}$ Jean Robertson and Craig McDaniel, Themes of contemporary art: visual art after 1980 (New York: Oxford University Press, 2005), 103.
} 
oppression. ${ }^{4}$ The relational aspect of identity and the shift from a focus on the individual to a focus on community can be linked to the deconstruction of the author-function. ${ }^{5}$ The author-function is different from a simple author or writer, most importantly, because it establishes a series of specific and complex operations resulting in a reference not purely to an individual but to an idea formulated by those operations. ${ }^{6}$

The author-function elevates the author to a mythical state of all-knowing, allseeing creator. ${ }^{7}$ Roland Barthes pronounced the "Death of the Author" in 1967 and the subsequent birth of the reader. ${ }^{8}$ Barthes argues that the Author ${ }^{9}$ is not antecedent to their work as a father is to a child, but rather is born simultaneously with their text, and "is in no way equipped with a being preceding or exceeding the text." ${ }^{\prime 10}$ Under this condition, to ascribe an Author to a work is to limit interpretation; therefore, killing the Author births the reader. Barthes' declaration shows preference for the reader because "the reader is the

\footnotetext{
${ }^{4}$ This is in addition to the feminist concern to validate women's personal experiences, represented by the phrase "the personal is political." See Carol Hanisch's original essay "The Personal is Political" in Notes from the Second Year: Women's Liberation; Major Writings of the Radical Feminists. New York: Radical Feminism, 1970, also available at http://www.carolhanisch.org/CHwritings/PIP.html. For the phrase in art, see Norma Broude, and Mary D. Garrard, eds. The Power of Feminist Art : The American Movement of the 1970s, History and Impact. New York: Abrams, 1994; Rozsika Parker, and Griselda Pollock. Framing Feminism: Art and the Women's Movement 1970-85. London: Pandora, 1987; and the video documentary: Laura Cottingham, Mary McEntire, Sally Sasso, Leslie Singer, and Yōko Ono. Not for Sale: Feminism and Art in the USA during the 1970s. New York: Hawkeye Productions, 1998.

${ }^{5}$ Michel Foucault identified the author-function in "What is an Author?" (1969), reprinted in The Critical Tradition, ed. David Richter (New York: St. Martin's Press, 1989), 978-988.

${ }^{6}$ Foucault, 985.

${ }^{7}$ There were historical and theoretical conflicts between emerging feminist principles and the so-called death of the author, the latter of which denied women agency in asserting their own identity-based narratives at the precise time that the collective women's movement sought to give voice to their personal experiences of oppression under patriarchy. Their narratives became the property of another (the reader), similar to how they have been historically seized by patriarchy.

${ }^{8}$ Roland Barthes, "Death of the Author," in Image, Music, Text (New York: Hill and Wang, 1978), 142-148.

${ }^{9}$ The capitalization denotes the differentiation from a writer/author to the Author or author-function that Barthes is describing.

${ }^{10}$ Barthes, 145.
} 
space on which all the quotations that make up a text are inscribed without any of them being lost; a text's unity lies not in its origin but in its destination."11

The forming of identity that privileges the individual's uniqueness, individualism, and self-determination is reflective of the author-function. Understanding one's identity through the author-function is similar to reaching a state of transcendent deification, which had previously been the privilege of white Western men. One accomplishes this through solitary, meditative practice and once it is reached, it infuses the individual with a god-like grace and self-knowledge. This state is self-evident and inherent, and can exist in solitude. The opposite approach to this is the path of the reader. In this sense, identity is formed and relational, not inherent; it is an accumulation of experiences, and changes as experiences change. As Barthes described a text's unity, identity here lies not in its origin, but in its destination.

To relate this specifically to art-making, because the unity of a work lies not in its origin but in its destination, its origin (the artist) can see the importance of engaging its destination (the community of viewers). Furthermore, if the artist is born simultaneously with the work, and the artist engages the destination of the work during creation, the identity of artists forms with the community of viewers. This process takes the artists' identity from natural or self-evident to relational and dependent upon communities, environments, and ideologies.

A relational perspective expands the focus of the artist. In addition to the mechanisms of the art world, such as the market, and its institutions and ideologies, the artist also focuses on the actors involved, from dealers and museum administrators, to individuals in their immediate family and community. Recognizing the separation or

\footnotetext{
${ }^{11}$ Ibid., 148.
} 
links between themselves and those mechanisms introduces an examination of power if the artist discovers differences between the two worlds. It reveals the dynamic between "us" and "them" and establishes the Other. The Other lies outside or in the margins of structures of power. Part of the discourse surrounding identity and power is the acknowledgment of the separation between those in the center and those at the margin. Groups in the center have power and the attention of the masses, while those at the margin are powerless, invisible and inconsequential. Individuals pushed away from the center lose power over their own lives and their own identities. Only after that center weakens, can the entire structure of power collapse.

In "Structure, Sign, and Play in the Discourse of the Human Sciences," Jacques Derrida recognizes that organizing a structure around a center "permits the play of its elements inside the total form." "Play" is the term Derrida uses to describe the limitlessness of what remains when structures are removed. The center functions to master anxiety, offering a reassuring certitude amid the uncertainty of play. ${ }^{13}$ With this realization, however, he asserts that anything with a center is constructed; and anything constructed is not fixed and can be deconstructed. He refers to the realization of this as a "rupture," where "the structurality of structure had to begin to be thought," and it became necessary "to begin thinking that there was no center... that it was not a fixed locus but a function... This was the moment when... in the absence of a center or origin, everything became discourse. ${ }^{\prime 14}$ Investigations of identity and power in contemporary art address the function of these centers and their surrounding frameworks.

\footnotetext{
${ }^{12}$ Jacques Derrida, "Structure, Sign, and Play in the Discourse of the Human Sciences," in Writing and Difference (Chicago: university of Chicago Press, 1978), 278-293: 279.

${ }^{13}$ Ibid.

${ }^{14}$ Derrida, 280
} 
Structures are formed to maintain power. Historically, that power existed exclusively in the hands of the privileged white male. As in most aspects of culture, those in power try to maintain a grasp on that power, resisting threats in any way that they can. The 1980s brought significant change to American culture, particularly in the arts. As more artists from the margin were making and showing art, organizations such as the National Endowment for the Arts created or enriched funding sources that mandated representation of these previously marginalized perspectives. ${ }^{15}$ These organizations mistakenly expected the majority of Americans to embrace the avant-garde viewpoint of these artists, and value the new perspectives. When the conservative Reagan administration and its supporters caught sight of the new art, funded by public grants and awards, that challenged sexism, racism, brought attention to the AIDS epidemic, addressed sexual experiences, or questioned religious beliefs, enormous controversies ensued. $^{16}$

The events that took place during this decade are often referred to as "the culture wars," when a series of contestations over cultural values resulted in the targeting of feminist, non-heterosexual, and non-white artists in public disputes over exhibitions, content, and government-funded projects. ${ }^{17}$ The shock of the AIDS epidemic mobilized many artists toward activism and into fierce investigations of power, marginalization, and its effects. Though the term "culture wars" denotes the disagreements in the public sphere between the conservative administration and the more liberal arts and creative sectors, the real war taking place in American culture was against the status quo, as women, non-

\footnotetext{
${ }^{15}$ Philip Yenawine, "But What Has Changed?" in Art Matters: How the Culture Wars Changed America, eds. Julie Ault, Brian Wallis, Marianne Weems, and Philip Yenawine (New York: New York University Press, 1999), 9.

${ }^{16}$ Yenawine, "But What Has Changed?," 11

${ }^{17}$ Robertson \& McDaniel, 13
} 
heterosexual, non-whites, and other groups who had previously been marginalized became aware and vocal in attempts to dismantle the structures that kept them in the margins.

In 1990, Lucy Lippard published a book entitled Mixed Blessings: New Art in a Multicultural America.${ }^{18}$ In the introduction, she asserts, "art with spiritual depth and social meaning is homeless in society, trapped in an art world dedicated to very different goals. The presence of more women and artists of color has changed some things about art, but it has not changed the art world much." ${ }^{19}$ At this moment in art history, Lippard speaks as a feminist art historian and critic, interested in a new focus on difference and identity in art, and the previous statement is her synopsis of the condition of the art world. At this point, art from Othered groups existed, but had not been "consecrated by the touch of the Quality wand" by the tastemakers, the curators, directors, historians, critics, gallerists, and others in power in the art world. ${ }^{20}$

Lippard's criticism of "Quality" is situated in the concept of quality within the author-function. Within this function, quality is innate, unchangeable, not influenced by outside forces. It is and always will be. Changes in artmaking, artistic practice, the artists themselves, or the market can never change understandings of quality. When Lippard wrote Mixed Blessings, artists from marginalized groups who were addressing identity did not merit contact with the Quality wand. This text, and others like it, became the child in the crowd unafraid to announce to the kingdom that the emperor is, in fact, naked. That "Quality" is actually just "quality," and is as vulnerable to a matrix of taste and preferences as in any other discipline.

\footnotetext{
${ }^{18}$ Lucy R Lippard, Mixed blessings: new art in a multicultural America (New York: Pantheon Books, 1990).

19 Ibid., 11

${ }^{20}$ Lippard, 8.
} 
Lippard calls an adherence to this myth of Quality a "sheeplike fidelity to a single criterion for good art-and such ignorant resistance to the fact that criteria can differ hugely among classes, cultures, even genders-remains firmly embedded in educational and artistic circles, producing audiences who are afraid to think for themselves. ${ }^{.21}$ She associates adherence to white, Western, patriarchal notions of quality with what Adrian Piper calls "cultural racism." This kind of racism is so damaging because it affects the victims' tastes and preferences, which when applied to their own self-image, makes them hate themselves. ${ }^{22}$ This kind of power seizes the psyche of the powerless and deeply alters their identity. The powerless do not think that they deserve power; they do not deserve a voice. They are robbed of their agency and are in effect, easier to control. Artists exploring issues of identity address hegemonic power structures directly, attempting to deconstruct and dismantle them. The prominence of identity work since the 1980 s is a result of this power struggle. Artists became aware that dismantling power structures meant that they could determine their own identities, or that their prescribed identities are only constructions and not truths. Their investigations of these realizations are present in their artwork. The next hurdle in the movement toward equality became representation.

\footnotetext{
${ }^{21}$ Lippard, 8.

${ }^{22}$ Lippard, 8.
} 


\section{IDENTITY AND POWER, AND THE ART MUSEUM NARRATIVE}

Othered artists faced considerable difficulty in representation. Historically, museums have had relatively exclusive rights to the Quality wand, wielding it and withholding it across generations through the narrative that they have established. The majority of the public only knows of art that they see in museums and then that art is included in history books, other art that is not deemed worthy for museums remains relatively unseen and rendered essentially nonexistent. Thus, representation is equated with power, while a lack of representation denotes powerlessness. Museums have long been considered free-choice learning environments, places where learning is chosen and sought, and also have the unique position of being places where meaning is made. ${ }^{23}$ Through access to objects and information, visitors see themselves and their culture reflected in ways that create meaning and learning. ${ }^{24}$

Meaning is made through the interplay between subjectivity and wider cultural understanding, often referred to as intersubjectivity. Intersubjectivity and the interplay between subject and object is an essential function of the museum. The museum's position as meaning-maker can have a powerful presence in the lives of the entire museum community, often contributing greatly to their sense of identity. Objects and information included in museums create meaning for visitors, but so does the exclusion of objects and information from museums. The inclusion/exclusion dynamic, combined

\footnotetext{
${ }^{23}$ Lynda Kelly, "Evaluation, Research and Communities of Practice: Program Evaluation in Museums," Archival Science, 4 (January 01, 2004): 1.

${ }^{24}$ Ibid.
} 
with information provided creates a narrative in the museum. The narrative that museums communicate influences the identity of their community.

Museums are social institutions, many of them nonprofits, abiding by standards established by the American Association of Museums and the International Council of Museums, whose Codes of Ethics state similarly that "Museums... are grounded in the tradition of public service. They are organized as public trusts, holding their collections and information as a benefit for those they were established to serve." ${ }^{, 25}$ This connection to public service gives the impression that museums are somehow neutral, as government ought to be, acting as the middle ground between the actors in the art world. As with any power structure, however, the position of neutrality is an illusion.

Hilde Hein investigates the formation of a canonical narrative in her essay entitled "Philosophical Reflections on the Museum as Canon Maker." ${ }^{26}$ Because of this illusion of neutrality, the judgments of value and quality in a museum are understood as depersonalized, rendering them "both public and normative, archivally retentive of objective value and to serve as legitimate celebrants of items of indubitable (if not universally acknowledged) merit." 27 This normative rendering of taste creates a message throughout the museum, a narrative as to what belongs, what does not, and who determines the participants. A museum paradigm that privileges the white, heterosexual male, hegemonic narrative operating under the normative assumption of Quality, maintains the same position that has built the structures of power throughout

\footnotetext{
${ }^{25}$ American Association of Museums. Codes of Ethics for Museums. http://www.aamus.org/museumresources/ethics/coe.cfm. Accessed October 9, 2011.

${ }^{26}$ Hilde Hein, "Philosophical Reflections on the Museum as Canon Maker," The Journal of Arts Management, Law, and Society. 22.4 (1993): 293-309.

${ }^{27}$ Hein, 295
} 
contemporary culture, the same narrative that has built the museum itself through the participation and dollars of donors, members, board members, and the curators and directors that shape the institution. A museum that excludes marginalized groups communicates a rejection of those groups, contributing to Piper's "cultural racism."

The preferences of these privileged few are mistaken for truth, their judgments made into canon. They do not merely relay the canon to their public, however, they also form the canon and the narrative that supports it. The function of meaning-making is similar to that of church, temple, or palace, which aids in transforming "ideology in the abstract into living belief." 28 These ceremonial monuments affirm the power and authority of a patron class, and impress society's most revered values and beliefs upon those who see or use them..$^{29}$ Upon entering the museum, the visitor feels a transformation from the everyday world to a space dedicated to the contemplation of higher values. ${ }^{30}$ This ritualistic experience opens the visitor up to the narrative; the museum itself becomes an ideology. Even the use of the term "canon" suggests ideology and belief of a holy stature, as it references ecclesiastical law, the selection of certain texts in keeping with religious doctrine, and the elevation of people to saintliness, ratified by the church. ${ }^{31}$ The meaning that museums make can carry unforeseen power, and send specific messages relating to identity.

\footnotetext{
${ }^{28}$ Carol Duncan and Alan Wallach, "The Museum of Modern Art as Late Capitalist Ritual: An Iconographic Analysis" (1978), in Grasping the World: The Idea of the Museum, ed. Donald Preziosi and Claire Farango (Aldershot, Hants, England: Ashgate, 2004), 483.

${ }^{29}$ Ibid., 483

${ }^{30}$ Ibid., 485

${ }^{31}$ Hein, 294
} 
In the second half of the nineteenth century, the museum was a medium for the development and realignment of social classes. ${ }^{32}$ In post-feudal society, museum displays communicated concepts of "national character and the emerging bourgeois narrative.",33 The intent of symbolic displays was to improve the morals of the people, rendering them milder and more obedient to laws. Pitt Rivers' displays of archeological objects were considered the ideal way to arrange artifacts for several generations. In his lecture to the Society of the Arts at Oxford in 1891 he proclaimed that, "the masses are ignorant... this opens them up to the designs of demagogues and agitators who strive to make them break with the past... in drastic changes that have not the sanction of experience. ${ }^{34}$ The museum's role was to educate the masses in accepting the existing social order. In the century following, it did not appear that these intentions changed very drastically.

The museum narrative is often present in their mission statements, which state that they aim to be conveyors of quality, to participate in a larger art historical dialogue, and to educate their communities. The Speed Art Museum's mission statement is "to discover, together with its communities, the joy and power of great art," and its vision statement is "to become an innovative museum nationally recognized for working with its communities to bring great art and people together in a spirit of joy, understanding, and constant discovery. ${ }^{35}$ Though no longer quite as devious, the narrative is subtle, but

\footnotetext{
${ }^{32}$ Kevin Coffee, "Cultural inclusion, exclusion and the formative roles of museums," Museum Management and Curatorship. 23.3 (2008): 261-279.

${ }^{33}$ Coffee, 267

${ }^{34}$ Annie E. Coombes, "Museums and the Formation of National and Cultural Identities" (1988) in Grasping the World: The Idea of the Museum, edited by Donald Preziosi and Claire Farango (Aldershot, Hants, England: Ashgate, 2004), 278-297.

${ }^{35}$ Speed Art Museum 2009990 Form, Accessed October 9, 2011, http://www.guidestar.org/FinDocuments//2009/610/444/2009-610444823-060c6a5d-9.pdf
} 
present, and still suggests a mission regarding the education of the masses on concepts of quality and history_ “great art"—deemed important by the institution.

One might argue that the entire purpose of an art museum is to communicate a narrative. In "Telling Objects: A Narrative Perspective on Collecting,"36 Mieke Bal recognizes that collecting itself is a narrative, a fetishistic inclination toward domination, operating in the Marxist-political critique; the alienated subjects gather things with which to surround themselves to satiate their incurable loneliness, the separation between subject and object. ${ }^{37}$ The act of collecting is the act of acquiring something that does not first belong to the collector. It is, in itself, an act of domination. It is difficult to demonize the whole system because as a culture, there is a shared interest in the preservation of objects, no matter who suffered in their acquisition. Perhaps this is due to the affects of the indoctrination of capitalism in our collective psyche, because we justify this domination and ownership by calling it storytelling, history making, cultural preservation, or collecting.

Being \& Making, however, proves that artists outside the art historical, white, heterosexual, male, hegemonic canon have made it into the collections of art museums even in cities like Louisville, whose population is $87.8 \%$ white. ${ }^{38}$ Has the paradigm truly shifted? Is the canon dismantled? The purpose of this paper is an attempt to answer those questions, however, part of the answer may lie in Hilde Hein's investigation of the museum as canon maker. She asserts that this was a movement to "enlarge the canon,"

\footnotetext{
${ }^{36}$ Bal, "Telling Objects: Narrative Perspectives on Collecting," (1994) in Grasping the World: The Idea of the Museum, edited by Donald Preziosi and Claire Farango (Aldershot, Hants, England: Ashgate, 2004) 84102.

${ }^{37}$ Bal, 91

${ }^{38}$ Data collected through Kentucky State Data Center 2009 and 2010 reports at http://ksdc.louisville.edu/1income.htm and http://ksdc.louisville.edu/.
} 
that is, not to do away with it completely. Certainly, the cultural and political demands of the 1980s and 1990s influenced museum collections, particularly in the area of contemporary art. Additionally, restructured tax laws in the 1980s and inflation in the art market meant that museums could no longer buy textbook masterpieces and were forced to change their acquisition interests. ${ }^{39}$ This financial incentive and a rising class of curators who were more inclined to accept the new, and less intimidated by the wrath of the established Quality wand and the canon, were more open to letting artists from marginalized groups into their collections.

The vast social movements since the 1970 s that have tried to change the canon, or at least to broaden it, heavily influenced the rising class of curators who felt inclined to look outside the canon. Feminism played a large part in this, as did various civil rights and social movements that brought attention to the absence of women and non-white people in art history. Linda Nochlin's seminal essay, "Why Have There been No Great Women Artists?," asked this important question in $1971 .^{40}$ The question of the absence of "women artists" extends to many other artists as well and relates to the historiography of art, and the idea of greatness formed throughout history. ${ }^{41}$ Nochlin frames the text as a series of confrontations to an understood natural order, beginning with a challenge to the very notion of what is accepted as natural. The neutral "one" in history, she argues, is actually the "white-male-position-accepted-as-natural, or the hidden 'he' as the subject of all scholarly

\footnotetext{
${ }^{39}$ Hein, "Canon Maker," 295

40 Linda Nochlin, "Why Have There Been No Great Women Artists?" (1971), Women, Art, and Power, (New York: Harper and Row, 1988), 145-178.

41 "Greatness" here is synonymous with the way I have been using the term "Quality."
} 
predicates." 42 The positioning of the presumed neutral "he" creates an advantage for men, as this viewpoint became the only one.

The illusion of neutrality is the shield behind which most forms of hegemonic narrative hide during their indoctrination into mass culture. Nochlin posits that "the domination of white male subjectivity" is a failure of history, and threatens intellectual fatality if it remains uncorrected. ${ }^{43}$ She identifies feminist critique as the method to reexamine history because it deals not only with the question of women, but also with the entire historical discipline. ${ }^{44}$ The problem is revealed not in the misconception of what women can accomplish, nor in what kind of artists women can be, but in the misconception about what art is. Art is perceived as a "direct, personal expression of individual emotional experience, a translation of personal life into visual terms." ${ }^{, 45}$ Nochlin corrects this naïve assumption by asserting, "the language of art... is neither a sob story nor a confidential whisper." whisper," suggests that great art is made through something innate, emotional, transcendent or secret. Here lies also the myth of the Genius or the Author, "an atemporal and mysterious power somehow embedded in the person of the Great Artist." ${ }^{, 47}$

More accurately, art is created and nurtured amid a socially constructed system, where access to that system requires practice, teaching, or extensive experimentation. Great women artists are absent from history not because women are incapable, but because the

42 Nochlin, 145

43 Nochlin, 146

44 lbid., 146

45 lbid., 149

46 lbid.

47 Ibid., 153 
process by which to obtain greatness has not been available. ${ }^{48}$ Women and Othered groups have not been given access to the privilege of an art education, the freedom of time, nor the support of cultural institutions necessary in achieving greatness. With this understanding, Nochlin issues a call to arms for women to combat this situation, ready to commit to the work needed to change the institutional sanctioning of men's art over women's with the full acknowledgment that those who are in power will hold on to that power as fiercely as they can. ${ }^{49}$ This war has been fought ever since, and is still raging, its soldier base broadening. At the frontlines, in the 1980s, a group of artists, calling themselves the "Guerilla Girls," formed to advocate for change in the canonical power structures dominant in art museums. They assembled wearing gorilla masks, and used pseudonyms of dead women artists from history to preserve their anonymity and metaphorically give a voice to these artists. They protested the openings to museum exhibitions that excluded even a small percentage of women and non-white artists claiming, "You're seeing less than half the picture without the vision of women artists and artists of color. ${ }^{, 50}$ They rented billboards, plastered posters, covered the walls of SoHo (the prominent art gallery district at the time) with quotes and statistics about the exclusion of women and non-white men from representation in art galleries and museums. Their advocacy became an integral part of the movement toward equal representation in the art world.

Linda Nochlin, the Guerilla Girls, and other scholars and advocates wrote texts, curated exhibitions, and organized academic programs aimed at correcting imbalances and inequalities against marginalized groups in the art world. New generations of curators rose out of these disciplines and through their presence the revolutionary influx

48 lbid., 147

49 lbid., 151-152

${ }^{50}$ Anna C. Chave, "The Guerrilla Girls' Reckoning," Art Journal, Vol. 70, Issue 2 (Summer 2011): 104. 
of investigations of identity prominent in the 1980 s and 1990 s were possible. Just as the tide was changing in art-making, exhibiting, and collecting, the entire museum paradigm also began to change. 


\section{IDENTIFYING THE ART MUSEUM VISITOR}

The new museology and the shift from inward focus to community focus is a direct response to a history of exclusion and elitism that threatens the downfall of many institutions. More than that, however, this shift toward the visitor is a shift in addressing identity, as many of the efforts in restructuring the museum have been in identifying, evaluating, and responding to the museum public. Museums saw the need to accession work by Othered artists. Subsequently, there is a parallel between representations of artists and the representation of their public. As the museum changes its focus from insular research to public participation, it is then under the eye of the public, its narratives intersecting with the public's personal histories and narratives. Since museums operated in such an exclusionary fashion for so long, there were vast discrepancies between the museum public and the actual community in which the museum was located. To correct this, significant resources have been devoted to identifying and evaluating museum visitors. In doing so, museums have revealed their own sets of identities and values; an evaluation of its community is also an evaluation of itself.

Toward the end of the twentieth century, museum administrators became anxious of how infrequently people visited museums. Museums performed studies on the characteristics of the museum visitor-they tended to be in higher education, income, and occupation groups, and tended to frequent other cultural leisure activities. ${ }^{51}$ This kind of demographic research gave administrators an idea of who the visitor might (and might

51 Marilyn Hood, "Staying Away: Why People Choose Not to Visit Museums," Museum News (April 1983): 50. 
not) be, but not why the visitor came. To understand this nuance, researchers began to focus on the psychographic characteristics of museum visitors - their values, interests, attitudes, perceptions, expectations, and satisfactions-their identities. ${ }^{52}$ Museums also became aware that research and evaluations needed to expand outside the museum so that their discoveries related to people who were not already a museum visitor. The goal of this kind of research was to understand how to get new visitors in the museum by offering programming that met their leisure activity needs, because research reveals that these needs determine whether or not visitors choose to visit museums.

What brings people into museums is similar to the things that bring them to any leisure activity. Adult museum visitors value social interaction, doing something worthwhile, feeling comfortable in their surroundings, having the challenge of a new activity, and having an opportunity to learn and actively participate. ${ }^{53}$ Often visitors that put more value in social interaction, or feeling comfortable and actively participating, did not visit museums and chose rather to take part in outdoor activities, going to the zoo or an amusement park, participating in sports, and other forms of leisure that often related to the family and revolved around children. These nonparticipants resembled the occasional participants, who visited museums once every year or two years. Occasional participants are socialized to value the museums, but preferred more active, family or friend-oriented leisure activities. ${ }^{54}$ In a detailed study conducted by the Toledo Museum of Art in Ohio from 1980-1981, researchers discovered that these two groups together comprised the majority of the Toledo public, $86 \%$ of the city's population. Museums were only

\footnotetext{
52 Ibid., 51

${ }^{53} \mathrm{lbid}$.

${ }^{54}$ Ibid., 54
} 
appealing to the remaining $14 \% .{ }^{55}$ Further investigation revealed that these numbers were consistent throughout museums in the United States.

It became clear to museum administrators that in order to engage the occasional and nonparticipant, programming needed to accommodate their interests. This meant adapting the delivery methods of museum messages by offering different levels of participation, comprehension, and involvement. ${ }^{56}$ What seems like a simple idea became a radical shift in museum operations. For centuries, museums only appealed to a small group of researchers, historians, and academics. The shock of the $14 \%$ and the threat of irrelevance pushed museums to reconsider their operations, programming and institutional ideologies, to welcome at least a portion of the $86 \%$. Museums are considered public institutions, and many receive public funding if not through direct grants from governments, then through the tax benefits of their nonprofit status. As public institutions, it became necessary to function for more than a small minority of that public.

Research into visitor participation has continued, and has become part of many institutions' regular operations. It is clear that in order to maintain relevance, museums need to analyze their audience and evaluate their programming to understand how they participate. Many of these studies, while a valuable step in identifying museum visitors' needs so that institutions can respond to them, still maintain a sense of elitism and dominance over what kind experiences people have in museums, and in what way they should participate. One such evaluation came from Phillip Yenawine, with the Museum of Modern Art and Visual Understanding in Education (VUE). Yenawine solicited the

\footnotetext{
${ }^{55}$ Ibid., 53-54

${ }^{56}$ Ibid., 56
} 
expertise of cognitive psychologist Abigail Housen to understand the learning strengths of museum visitors so that museums can form their exhibitions and programming with this in mind. ${ }^{57}$ This evaluation rose out of a series of surveys conducted on visitors of the Museum of Modern Art in 1986, and were interpreted in 2001 in a model to describe museum visitors. Though the VUE study is only one example, similar results to these were seen across the museum sector from the surveys and evaluations conducted on the museum visitor.

VUE arranges visitors' learning capabilities into five stages of aesthetic development. The first two stages, Accountive and Constructive viewers, respond to art subjectively, without a historical framework. ${ }^{58}$ These first stages are not to be considered ignorant, but rather at an early developmental stage. ${ }^{59}$ The third through fifth stages, Classifying, Interpretive, and Re-creative viewers, approach that of experts and usually have some art historical knowledge or are art historians themselves. The first two stages represent the majority of the museum public.

Stage 1 and 2 viewers often have little exposure to art, and at Stage 1 they are unaware that their lack of exposure greatly influences their opinions of work. Individuals at this stage of aesthetic development often ask the question, "Why is this art?," particularly in relation to what may seem "weird. ${ }^{, 60}$ Stage 2 viewers often define art by technical skill or conventional ideas of beauty. They respond to information and explanations and have sincere interest in learning how to understand art and often

\footnotetext{
${ }^{57}$ Phillip Yenawine, "Writing for Adult Museum Visitors." New York: Visual Understanding in Education. 2001, Accessed October 15, 2011: http://www.vtshome.org/system/resources/0000/0212/writing for adult mus visitors.pdf

${ }^{58}$ Ibid., 13

${ }^{59}$ Ibid., 5

${ }^{60}$ Ibid., 5
} 
welcome the opportunity to form their own conclusions and interpretations. Stage 3, 4, and 5 viewers adopt analytical and critical stances similar to that of the art historian. They move through classifying time periods, genres, and eras, into symbolism and interpretation, and finally arrive at the most sophisticated state, full re-creative participation, where the work of art is "like an old friend," and their own identity is fused with the work of art. ${ }^{61}$

Brochures, wall labels, and audio tours help to set the foundation for interpretation. Stage 1 and 2 viewers often want to know the context in which the art was made and even the artist's intentions. ${ }^{62}$ Stage 2 viewers often respond to human interest elements in museum text such as the artist's culture, emotional state or values. Often considering what a museum visitor already knows is more important than what they do not know. Understanding what they are bringing with them when they first look at a piece can help foster a connection with the work. As with other structures of learning, VUE determined that one stage can and should grow into another. The more comfortable and confident a viewer becomes looking at art, the more advanced their aesthetic development becomes.

This kind of research has brought about significant changes in the way museums label and interpret art. VUE has used these evaluations to reach conclusions about how to write labels, how long they should be, what kind of vocabulary is acceptable, and other important features. For example, VUE states that labels should outline why the work is important and supply a frame of reference for "difficult" art. ${ }^{63}$ Labels should also use plain language, avoid art lingo or jargon, and provide definitions for any necessary

\footnotetext{
${ }^{61}$ lbid., 13

${ }^{62}$ Ibid., 8

${ }^{63}$ Ibid., 10
} 
jargon. These developments are essential and groundbreaking. They provide availability for everyone to come into a museum, look at the art or artifacts, read the labels, and walk away with a valuable experience.

This ranking system, however, and the view that some adult museum visitors are "at an early developmental stage" is problematic. This type of characterization implies that there is one optimal way to visit a museum, at the fifth stage. All visitors at the first four stages are essentially weaker participants. It maintains an exclusionary structure of participation and implies that all visitors should work toward entrance into the zenith of the fifth stage. A visitor's own sense of identity might never prompt them to enter into that fifth stage. Despite all the evaluation that has gone into visitor participation, researchers at this point still did not recognize the diversity in individual identities and the importance in offering the kind of participation that would meet all stages, without this museum caste-system structure motivating that engagement.

John H. Falk has been an active participant in an identity-centered approach to understanding museum learning. ${ }^{64}$ Recognizing that people enter museums with an entire lifetime of experiences with them, Falk advocates that focusing on visitors' identity is the optimal way to understand their motivations and expectations of museums.

Understanding that identity is not fixed, Falk recognizes that on any given day, a museum visitor might have different identity centered needs. For example, on a vacation, a visitor would be interested in the role of a tourist, while on a Sunday afternoon in their hometown, a visitor might be more interested in their role as a parent taking their child to

\footnotetext{
${ }^{64}$ John H. Falk, "An Identity-Centered Approach to Understanding Museum Learning," Curator: The Museum Journal, 49.2 (2006): 151-166.
} 
see a museum. ${ }^{65}$ No matter the role or prominent facet of one's identity, that is what motivates the visitor's visit, and the success of that visit will be dependent on the expectations of that aspect of their identity. In response, museums should diversify their programming to cover the identity spectrum of the museum visitor.

Falk categorizes that spectrum into five clusters of closely associated identityrelated motivations: the Explorer, the Facilitator, the Professional/hobbyist, the Experience Seeker, and the Spiritual Pilgrim. ${ }^{66}$ Curiosity motivates Explorers. They like seeing and learning new things so they are drawn to places that provide that experience. The needs of another person motivate the Facilitator: their child, or a romantic interest, spouse or partner, or a visiting relative. Usually these visitors are convinced of a need or benefit of patronizing cultural institutions and want to provide their loved one with that valuable experience. The Professional/hobbyist is similar to the Explorer; however, their curiosity is at another level of commitment and they spend significant time researching and learning about the content of the institution. Often they are more interested in how the museum conveys the information, rather than what it conveys. They are teachers, or doctors visiting science centers, art historians visiting art museums, sometimes they are parents who are homeschooling their children. They are interested in enhancing their profession, avocation, or hobby. ${ }^{67}$

The Experience Seeker is an experience collector; they want to say they went to a city and experienced the cultural institutions. They value the recreational aspect of the experience and often only remember humorous or extreme experiences. Experience Seekers do not make learning a priority. The Spiritual Pilgrim is the rarest of the five

\footnotetext{
${ }^{65}$ Ibid., 154

66 Ibid., 156

${ }^{67}$ Ibid., 157
} 
groups. They look to cultural institutions for a connection to wonder and introspection, almost reverentially. Over the course of extensive study at multiple cultural institutions, Falk concluded that the majority of visitors could be categorized by a combination of the five identity-centered traits, resulting in roughly twenty-five categories that combine the five traits in unique ways. ${ }^{68}$ These findings further support the claim that museums should aim their programming toward a spectrum of visitor identities and offer the understanding that museum visitors do not need to be ranked.

Motivations for museum visits are so complex that museum administrators should focus more on the visitors themselves rather than on shaping the visitor to fit the museum narrative. Many other studies have been conducted on visitor participation, resulting in similar conclusions; some studies rank visitors, some do not, but all of them categorize similarly. Most of them, especially the more recent studies, recognize that museum programming benefits from accommodating the spectrum of visitors.

I will conclude this review of the visitor evaluation with the most recently published study recognized as the most groundbreaking, conclusive, most deeply researched study to date- the seven-year study by the Dallas Museum of Art (The DMA): Framework for Engaging with Art (The FEA) ${ }^{69}$ This evaluation was extensive and related to the museum community as a whole, including children and their teachers, and included an extensive use of survey and interview collection methods. It was also part of a museum-wide re-imaging and reconfiguring, and affected the museum's employment structure, branding, operations, and even included building renovations. For

\footnotetext{
${ }^{68}$ Ibid., 160

${ }^{69}$ The framework can be accessed online through the museum's website at http://dallasmuseumofart.org/AboutUs/Frameworkforengagingwithart/index.htm or can be seen in their related book: Bonnie Pitman and Ellen Cochran Hirzy. Ignite the power of art: advancing visitor engagement in museums. (Dallas: Dallas Museum of Art, 2010).
} 
the purposes of this paper, I will focus on the conclusive summaries of research done on the onsite, adult museum visitor.

The DMA conducted the study between 2003 and 2009 with the help of Randi Korn and Associates, Inc. (RK\&A), the widely used specialists on museum evaluations. The research began with a series of qualitative questions or statements about how visitors prefer to engage with art and their comfort levels in looking at and talking about art. ${ }^{70}$ Interviewers followed these questions with conversations that allowed for additional information. The survey was conducted onsite with over 1,500 visitors, and online with another 1,400 participants. ${ }^{71}$ The research identified four "visitor clusters" or types based on these preferences, moving beyond the simple, singular, characterization of visitors into understanding the multi-dimensional identity-based set of characteristics. This was done with the purpose of "enabling museums to understand their audiences and better shape their offerings to address varying visitor interests and needs." 72

The responses to the following statements became the foundation of this surveybased research:

1. I feel comfortable looking at most types of art.

2. I like to know about the story portrayed in a work of art.

3. I like to know about the materials and techniques used by the artist.

4. I enjoy talking with others about the art we are looking at.

5. I am emotionally affected by art.

6. I like to be told a straightforward insight to help me know what the work of art is about.

7. I like to view a work of art on my own, without explanations or interpretations.

8. I am comfortable explaining the meaning of a work of art to a friend.

9. I like to connect with works of art through music, dance, dramatic performances, and readings.

10. I find some terms used in art museums difficult to understand.

\footnotetext{
${ }^{70}$ Ibid., website

${ }^{71}$ Ibid., book, 36

72 Ibid., book, 39
} 
Based on visitors' self-evaluated ratings of these 10 statements using a scale from 1 (does not describe me) to 7 (describes me very well), ${ }^{73}$ and also additional interviews based on the answers to the ten foundation statements, the DMA and RK\&A grouped visitors into four distinct clusters. These four clusters are Observers (26\%), Participants (24\%), Independents (20\%), and Enthusiasts (30\%). ${ }^{74}$

Among Observers, ${ }^{75} 48 \%$ have taken art history or art appreciation classes; $19 \%$ have taken studio art classes; $4 \%$ describe themselves as artists; $27 \%$ visit other cities to see art; $58 \%$ use the internet to find out about art exhibitions and events; $30 \%$ are first time visitors; $31 \%$ are DMA members; $60 \%$ are male and $40 \%$ are female. Observers are engaged, participate, and often stay informed about exhibitions and events. They are usually new to the art world, and are somewhat tentative about their knowledge. They gave low numbers to the question of being emotionally affected by art, and tend to prefer straightforward explanations of works of art. The DMA determined that Observers are best reached by good accessibility options (parking ease, guest services, etc.), clear introductory materials, fun and entertaining experiences, straightforward language, participation with family and friends, and opportunities to learn the basics of art viewing. Participants ${ }^{76}$ are comfortable looking at art, enjoy the learning and social aspects of museum visits, usually have a strong knowledge of art, like to connect with art through music, dance, and dramatic performance, and actively use interpretive resources and programs. Seventy percent have taken art history or art appreciation classes; $35 \%$ have taken studio art classes; $29 \%$ describe themselves as artists; $48 \%$ visit other cities to see

\footnotetext{
${ }^{73}$ See Table 1 at the end of this chapter for table of results

${ }^{74}$ See Table 2 at the end of this chapter for table of results

${ }^{75}$ The following is summarized from lbid., 44-53

${ }^{76}$ Ibid., 55-63
} 
art; $76 \%$ use the internet to find out about art exhibitions and events; $30 \%$ are first time visitors; $33 \%$ are DMA members; $38 \%$ are male and $62 \%$ are female. They benefit from opportunities for social interaction and intellectual engagement, creative connections to art through music, dance, and drama, acquiring new skills in art making and creativity, a variety of communication and program formats, and socializing in the museum.

Independents $\mathrm{s}^{77}$ engage intensely, they are educated and confident about their knowledge of art, and they enjoy a museum where they can slow down and focus on the art, and perhaps discuss it with others. Seventy-three percent have taken art history or art appreciation classes; $41 \%$ have taken studio art classes; $32 \%$ describe themselves as artists; $41 \%$ visit other cities to see art; $74 \%$ use the internet to find out about art exhibitions and events; $28 \%$ are first time visitors; $32 \%$ are DMA members; $52 \%$ are male and $48 \%$ are female. These visitors like the opportunity to experience art on their own, without interpretation. They prefer freedom in the museum and value a variety of options for participation in programming. They also value intellectual rigor, access to scholarly research and art and museum professionals, and settings that encourage intense inspection and reflection on works of art.

Enthusiasts ${ }^{78}$ are true to their name, they are confident, knowledgeable, and enjoy all types of art. They connect with art emotionally, participate widely in museum programming, and are often artists themselves. Eighty-two percent have taken art history or art appreciation classes; $55 \%$ have taken studio art classes; $35 \%$ describe themselves as artists; $66 \%$ visit other cities to see art; $83 \%$ use the internet to find out about art exhibitions and events; $12 \%$ are first time visitors; $50 \%$ are DMA members; $25 \%$ are

${ }^{77}$ Ibid., 64-73
${ }^{78}$ Ibid., 75-83 
male and $75 \%$ are female. The DMA recognizes that the Enthusiasts value museum programming that links "the Museum and works of art to life experiences," suggesting that this group, more than all the others, considers the Museum as part of their own identity. $^{79}$

Researchers have also taken this information and applied it to museum programming. They have determined which groups enjoy looking at works of art, reading explanatory wall text, experiencing musical or theatrical performances in the galleries, watching video in the galleries, responding to art by creating art, taking a guided tour, using reading areas in the galleries, using computers to learn about art, or a combination of those activities. This framework helps the museum pinpoint what programming serves the needs of the different clusters, and where certain groups may be under-stimulated or underserved.

Observers have the weakest connection to art museums, in that they tend to choose other activities over art museum visits. The DMA has been able to cater certain programs like their "Late Nights at the DMA" program where the museum is open until midnight once a month and each event offers different kinds of programming. For the Observers, the DMA has taken this social event into the outdoor space of the museum campus to offer concerts, film screening, artist demonstrations, and family activities. ${ }^{80}$ The Late Nights offer visitors who are unable to come during daytime hours a chance to engage with the museum. The myriad of programs offered during these late nights is

\footnotetext{
${ }^{79}$ bid., 82

${ }^{80}$ Ibid., 169
} 
diverse and engages all the clusters in one setting, for one event. ${ }^{81}$ In many ways, this event is the concentration of all the museum programming in one evening.

While evaluations like VUE maintain museum hierarchies and the canonical narrative by imposing expectations on visitors, the DMA study meets visitors where they are, and as a public institution, forms their programming to meet their communities. This eradicates the insular, exclusivity of the canonical museum and opens it up to a wider public. Addressing identities allows the museum to bring the diverse populations into the institution by offering programming that activates their leisure, learning, and intellectual interests. By doing this, the museum narrative expands as its public does, and the museum community looks more like its actual community. In numbers alone, the DMA's attendance has grown from 337,000 in 2002 to 900,000 in $2009 .^{82}$

One could imagine a museum might receive criticism for providing programming like concerts, workshops, and children's activities, suggesting that these activities devalue the museum. Museums, however, are not serving their public by maintaining canonical notions of viewership and participation. When something is not working, when the public is dwindling, institutions respond or face extinction. A museum full of art that is only accessible to scholars and historians proves of little use to the majority of the public. Certainly scholarly research can still be preserved, and respect and care maintained for the objects themselves, but this can all be done while programming is increased. As the museum changes its focus from insular research to public participation, its narratives intersect with the public's narratives, and becomes part of their lives. In doing this, museums revealed a new identity and a new set of values that puts its public at

\footnotetext{
${ }^{81}$ Ibid., 170

${ }^{82}$ Ibid., 216, The source did not mention what percentage was repeat visits.
} 
a higher level of importance, and recognizes that a diverse museum is a richer institution. The study conducted by the DMA is the fullest incarnation of the new museology. 


\begin{tabular}{|c|c|c|c|c|c|}
\hline Questions & $\begin{array}{c}\text { TENTATIVE } \\
\text { OBSERVER } \\
(26 \%) \\
\text { Mean } \\
\end{array}$ & $\begin{array}{c}\text { CURIOUS } \\
\text { PARTICIPANT } \\
(24 \%) \\
\text { Mean } \\
\end{array}$ & $\begin{array}{c}\text { DISCERNING } \\
\text { INDEPENDENT } \\
(20 \%) \\
\text { Mean } \\
\end{array}$ & $\begin{array}{c}\text { COMMITTED } \\
\text { ENTHUSIAST } \\
(30 \%) \\
\text { Mean } \\
\end{array}$ & Total \\
\hline $\begin{array}{l}\text { I feel comfortable } \\
\text { looking at most types } \\
\text { of art. }\end{array}$ & 5.5 & 6.6 & 6.7 & 6.8 & 6.4 \\
\hline $\begin{array}{l}\text { I like to know about the } \\
\text { story portrayed in a } \\
\text { work of art. }\end{array}$ & 6.0 & 6.5 & 4.7 & 6.4 & 6.0 \\
\hline $\begin{array}{l}\text { I like to know about the } \\
\text { materials and } \\
\text { techniques used by the } \\
\text { artist. }\end{array}$ & 4.6 & 6.1 & 5.1 & 6.3 & 5.7 \\
\hline $\begin{array}{l}\text { I enjoy talking with } \\
\text { others about the art we } \\
\text { are looking at. }\end{array}$ & 4.5 & 6.3 & 5.9 & 6.3 & 5.7 \\
\hline $\begin{array}{l}\text { I am emotionally } \\
\text { affected by art. }\end{array}$ & 4.3 & 5.9 & 5.6 & 6.4 & 5.6 \\
\hline $\begin{array}{l}\text { I like to be told a } \\
\text { straightforward insight } \\
\text { to help me know what } \\
\text { the work of art is } \\
\text { about. }\end{array}$ & 5.6 & 6.0 & 3.0 & 6.0 & 5.3 \\
\hline $\begin{array}{l}\text { I like to view a work of } \\
\text { art on my own, without } \\
\text { explanations or } \\
\text { interpretations. }\end{array}$ & 4.4 & 4.8 & 6.1 & 5.0 & 5.0 \\
\hline $\begin{array}{l}\text { I am comfortable } \\
\text { explaining the meaning } \\
\text { of a work of art to a } \\
\text { friend. }\end{array}$ & 2.9 & 5.2 & 5.1 & 6.1 & 4.8 \\
\hline $\begin{array}{l}\text { I like to connect with } \\
\text { works of art through } \\
\text { music, dance, dramatic } \\
\text { performances, and } \\
\text { readings. }\end{array}$ & 3.0 & 5.4 & 4.2 & 5.1 & 4.4 \\
\hline $\begin{array}{l}\text { I find some terms used } \\
\text { in art museums are } \\
\text { difficult for me to } \\
\text { understand. }\end{array}$ & 3.8 & 5.6 & 2.6 & 1.6 & 3.3 \\
\hline
\end{tabular}

Table 1: Results of questionnaire conducted by the DMA and RK\&A

\footnotetext{
${ }^{83}$ Pittman, 84
} 


\begin{tabular}{|c|c|c|c|c|c|}
\hline $\begin{array}{c}\text { Art Related } \\
\text { Activities } \\
\text { Background }\end{array}$ & OBSERVERS & PARTICIPANTS & INDEPENDENTS & ENTHUSIASTS & OVERALL \\
\hline $\begin{array}{l}\text { Has taken } \\
\text { an art } \\
\text { history or } \\
\text { art } \\
\text { appreciation } \\
\text { class }\end{array}$ & $48 \%$ & $70 \%$ & $73 \%$ & $82 \%$ & $69 \%$ \\
\hline $\begin{array}{l}\text { Has taken } 2 \\
\text { or more art } \\
\text { history or } \\
\text { art } \\
\text { appreciation } \\
\text { classes } \\
\end{array}$ & $25 \%$ & $50 \%$ & $53 \%$ & $68 \%$ & $49 \%$ \\
\hline $\begin{array}{l}\text { Visited a } \\
\text { city } \\
\text { specifically } \\
\text { to see art in } \\
\text { the past } 12 \\
\text { months }\end{array}$ & $27 \%$ & $48 \%$ & $41 \%$ & $66 \%$ & $47 \%$ \\
\hline $\begin{array}{l}\text { Has taken } \\
\text { studio art } \\
\text { classes }\end{array}$ & $19 \%$ & $35 \%$ & $41 \%$ & $55 \%$ & $38 \%$ \\
\hline $\begin{array}{l}\text { Attended a } \\
\text { lecture or } \\
\text { symposium } \\
\text { in an art } \\
\text { museum in } \\
\text { the past } 12 \\
\text { months }\end{array}$ & $14 \%$ & $34 \%$ & $20 \%$ & $49 \%$ & $31 \%$ \\
\hline $\begin{array}{l}\text { Is a } \\
\text { practicing } \\
\text { artist }\end{array}$ & $4 \%$ & $29 \%$ & $32 \%$ & $35 \%$ & $25 \%$ \\
\hline $\begin{array}{l}\text { Is a DMA } \\
\text { member }\end{array}$ & $31 \%$ & $33 \%$ & $32 \%$ & $50 \%$ & $38 \%$ \\
\hline
\end{tabular}

Table 2: Background information about visitors by cluster by DMA and RK\&A ${ }^{84}$

${ }^{84}$ Pittman, 87 


\section{ADDRESSING IDENTITY/REDRESSING THE MUSEUM}

Studies like the DMA's put theory into practice through museum programming and activities. Targeting the visitor is an important step in reshaping the museum to be more inclusive and, in that regard, challenges the canon. This does not address, however, museum operations that relate to collecting and exhibiting art. The DMA's studies have led them to understand what kind of exhibitions attract visitors, and how each exhibition's interpretation materials can be formatted and worded to benefit broad audiences. What happens, however, when a curator sits down to write an exhibition text; or when a collection committee gathers to vote on a work of art for accession by the museum? Considering the audience can only guide those individuals with part of the decision, the canon is there for the rest of it.

In order to complete the shift from being about something to being for someone museums will need to adopt a methodology that covers all aspects of museum operation. That methodology will either conform to the canon, continuing to show preference for a history of exclusion and oppression, or will have to difference the canon. Differencing the canon and redressing the museum is the only way to complete a paradigm shift in museum practice, as the exclusionary practices opposed by the new museology are those that suppress identity and sanction the canon. Feminism is perfectly poised to be that methodology.

The first section of Griselda Pollock's Differencing the Canon, is cleverly titled after a panel Linda Nochlin formed in the 1990s- "Firing the Canon." With the poignant 
play on words, she recognizes that, "the discourse of the Other must, of necessity difference the canon." impoverishing filter for the totality of cultural possibilities, generation after generation."86 In consideration of the participation of diverse identities in art, questioning this canon is essential. The narrative that limits representation is the narrative that has enabled the canon to maintain power.

Can a movement towards a more inclusive paradigm really fire the canon? Pollock argues that this would result in another segregated model- which privileges one set of identities and repudiates the other. She stresses the importance of the active tense of the word "differencing," saying that the movement away from the canon must happen both by and in, while it is simultaneously against the discourse of the canon. She quotes Theresa de Laurentis who displaces the opposition between the inside/outside nature of the canon and recognizes feminism as a "view from elsewhere... it is the elsewhere of discourse here and now, the blind spots, or the space-off of its representations... the spaces in the margins of hegemonic discourse, social spaces carved in the interstices of institutions and in the chinks and cracks of the power-knowledge-apparati." words, it has been there all along. The discourse of the Other has always been a silent part of the canon, and feminism illuminates that which is "not-represented, yet implied. ${ }^{, 88}$ Differencing the canon does not obliterate the canon, but rather illuminates the parts left dark.

85 Griselda Pollock, Differencing the Canon: Feminist Desire and the Writings of Art's History. (New York: Routledge, 1999): 5

86 Ibid., 4

${ }^{87}$ Ibid., 7-8, emphasis added

${ }^{88}$ Ibid., 8 
Hilde Hein advocates for a re-dressing/redressing of the museum in feminist theory and for a change in exhibition and collection policies and practices. ${ }^{89}$ The pluralism in feminist theory allows the museum to abandon canonical separation of objects, to consider the relationship between subject and object, to reconsider the notion of the masterpiece, and the exclusion of marginalized groups from participating in art history. These modifications can conceptually restructure the way that museums exhibit, interpret and collect. She observes the trends in the new museology, the movements toward understanding museum visitors, the efforts to expand the visitor base, and recognizes that despite all these efforts, museums are still floundering, their efforts aggravating rather than assuaging the general dissatisfaction. ${ }^{90}$ Though the DMA's study may prove different results, Hein acknowledges that the experience-oriented approach to museum learning "aims to transcend the object, but sometimes succeeds only in objectifying experience according to a standard and market-designated pattern."${ }^{.91}$

The new museology already resembles feminism. Literature of the 1970s and 1980s, some reviewed in this paper, was concerned with challenging arts institutions, including museums, galleries, and academic institutions. The movement toward an emphasis on identity was a combination of poststructuralist and feminist ideologies that confronted canonical power structures that created the exclusionary practices of historic institutions. Even science museums are less about celebrating the "great originators" and

\footnotetext{
${ }^{89}$ Hilde S. Hein, "Redressing the Museum in Feminist Theory," Museum Management and Curatorship, 22.1 (2007): 29-42.

${ }^{90}$ Ibid., 29

${ }^{91}$ Ibid., 31
} 
more about the process of understanding the world, less about individual genius and more about exploring patterns that infuse and inspire societies. ${ }^{92}$

Feminism is pluralistic in nature; there is no single feminist theory, no single feminist canon, but rather there are four important declarations that Hein describes as the basis for the kind of feminism to which she refers. First, feminism is not predominately about women. Although it arises out of the experience of women, its aim is not equality with men, but a conceptual restructuration of the cultural disequilibrium that allows the possibility of ownership and power entitlements in the characterization of the human subject. ${ }^{93}$ Feminism is not a movement to overthrow the reign of men and replace the positions of power with women, but to restructure the entire system that allows for domination, subjectivity and otherness.

The second restructuration necessary in feminist theory is the subject/object polarity, and the "hierarchy that assigns unequal value to the poles." 94 This too is a deconstruction of power that blurs the distinction between "agent and acted-upon, [she proposes] instead a continuity of identity and process that is reflexive and adapts to its shifting environment." $" 95$ The notion of fluidity reappears here, as in Derrida and Pollock. The moment where process becomes fixed, power inequalities emerge. It is only in the active tense where play resumes, and though inevitably in existence, power structures begin to weaken.

The third facet of feminist theory crucial to its adoption in museum practice is the very notion of identity reviewed throughout this paper- the repudiation of the adulation of

\footnotetext{
92 Ibid., 39

${ }^{93}$ Ibid., 32

94 Ibid.

95 Ibid.
} 
the autonomous individual, the Author. Social life should instead promote integrated relationships between self and other, self and nature, in an environment that is not oppressive/repressive. ${ }^{96}$ Identity here is relational, where the very idea of difference is not a measure of $u s$ versus them. Lastly, feminism rejects sharp delineations and fixed systems of classifications; it accommodates impermanence and does not assign preference to permanence. ${ }^{97}$ Through this, it is responsive and dynamic, once again active rather than fixed.

Under this methodological framework, museums can address many of the canonical customs that prevent its complete progress into the new museology. Hein identifies these obstructions as a lack of self-conscious engagement, the persistent approbation of the masterpiece, fixity of boundaries, and the impression among the museum public that it is a place for possession and consumption of art and artifacts, rather than a place for participation in process.

The detachment and casual attention of the flaneur plagues the museum still, with visitors zombified in the presence of neutralized objects sanctioned by the "authoritative voice of the museum. ${ }^{, 98}$ Neutralization occurs from the passivity that museums ask of its audience, and of its objects under the museum's authority. A museum redressed in feminist theory analyzes and questions its own authoritative systems, "de-neutralizing both object and audience." 99 This de-neutralization restores engagement and participation. A viewer who is self-aware, whose agency is not obstructed by the

\footnotetext{
${ }^{96}$ Ibid., 33

97 Ibid.

98 Ibid., 34

99 Ibid., 35
} 
authoritative voice of the museum, is free to operate within that agency and interact actively with the museum, thereby solving the continuing problem of participation. ${ }^{100}$

Hein suggests that museums depart from highlighting masterpieces in their collection, not because of the quality of the works of art, but because of the "weighted criteria for choosing them and the limited range of candidates and judges." ${ }^{101}$ Hein's argument here aligns exactly with Nochlin's on the absence of women artists from history. Even the very word "masterpiece" denotes a male author. ${ }^{102}$ This inherently represents its configuration under canonical power structures. Oppression is inherently part of the history of any discipline, even art history. If a conceptual restructuration and a differencing of the canon is part of the new museology, then so is the dissolution of a preference for the masterpiece. This argument flows well into Hein's advocacy for the decomposition of boundaries in museums. Even boundaries relating to medium express a hierarchy- a painting and a tapestry are worlds apart in the museum, and those major differences were inherited through the canonical separation of objects and the history of preference for one medium over another, these preferences often relating to gender, class, and cultural discriminations.

The final obstruction on the path to the new museology is the mistaken assumption that a museum is a sanctuary for the preservation of precious objects. Many other enclosures serve this purpose. The difference between a museum and a bank, a private collection, or an expensive store is its agency, what it does with its resources and

100 lbid., 35

${ }^{101}$ Ibid.,36

${ }^{102}$ Ibid., 34 
for whom; "it is an actor among actors and is distinguished by its action." ${ }^{\text {"103 }}$ It is not about or for something- it is for someone.

Suzanne Oberhardt proposes the existence of four frames in the deconstruction and reconstruction of the museum. ${ }^{104}$ These frames represent the prescribed identities of museums as they have existed throughout their history, their ideological and social constructions. Under poststructuralist methodology, once an ideology's frame is recognized, complete with its arbitrary and fallacious borders, it can be deconstructed. ${ }^{105}$ Frame 1 is the canon, the adored art museum, deified and authoritative. Frame 2 is the new museology, which Oberhardt says demonizes the museum, and makes it an agent of oppression. In Frame 3, the museum shifts into popular culture, leaves academic discourse altogether and its identity is defined in the way that society represents and talks about the museum. In this frame, the museum is romanticized, made part of familiar locales and commonly associated with romantic love; "it sits in the position of the postage stamp and of the heart," and it is once again sacred and beloved. ${ }^{106}$

The fourth frame hovers over these three frames, acknowledging their existence but refuses to see each frame as mutually exclusive, which means that there is no need for any single frame to be reconciled or integrated, nor does one frame need to be more dominant than the rest. ${ }^{107}$ Oberhardt calls Frame 4 "the big picture" revealing that while we can never really eliminate cultural structures (or frames), what we can strive for is

\footnotetext{
${ }^{103}$ Ibid., 38

${ }^{104}$ Suzanne Oberhardt, "Frames within Frames: The Pedagogy of the Art Museum as Cultural Artifact, (doctoral dissertation, Pennsylvania State University, 2000), 240. (Also published: New York and Washington: Peter Lang, 2001) This text was review in Griselda Pollock, "Unframing the Modern: Critical Space/Public Possibility" in Griselda Pollock and Joyce Zemans, eds. 2007. Museums after modernism: strategies of engagement. Malden, MA: Blackwell, 1-36.

${ }^{105}$ ibid., 2.

${ }^{106}$ Ibid., 9

${ }^{107}$ Ibid., 9-10
} 
"the continued deconstruction of prevailing frames for the purpose of creating new ones: each attempt resisting odious and dominant world views and creating fresh meanings, identities and fairer ways of life. In the shift from a relatively static culture to a global, corporate and electronic culture which constantly invents and reinvents itself, we can come to know the art museum differently." 108 Frame 4 positions the museum in a state of perpetual deconstruction, with the main purpose of recreation and discovery, and a movement away from the oppression of previous ideologies.

In Being and Making, I attempt to follow the trajectory of feminist and poststructuralist museum methods in both content and execution. The media included varies, from porcelain to electronic media; even exploiting the histories of the media, and collapsing the hierarchies that separate techniques, materials, and traditions. The work is diverse and representative of several types of identity investigations. It contains many of the expected manifestations of identity themes- race, culture, class, sexuality, and gender, but includes two works that are less likely to appear in this type of exhibition. Sarah Lyon's and Chris Radtke's works are actually void of many of the previously mentioned identity characteristics, and instead appeal to a more universal experience- a sense of place, and physicality. In a city with a population that is nearly $90 \%$ white, an exhibition on identity could not only represent the identities of minority groups. Including these two artists' work unites the theme of identity across experiences, races, genders, and classes, and furthers the argument that identity is fluid and universal.

In the execution of the exhibition text, I considered the results of the evaluations I reviewed. Through these evaluations, I understand that audiences need context, interpretation, some explanation of process or materials, and room for further

${ }^{108}$ Ibid., 10 
interpretation. Offering this information helps give the viewer a sense of belonging through participation. Engaging with the art allows the viewer to make a connection with not only the work, but hopefully the collective exhibition. In order to aid in this process, I provide a label for each piece of art, empowering the visitors' participation with every piece as part of a whole. I avoid giving authority to the artist/author and focus on the content of the work and the themes presented as a function of an investigation, an ongoing process of discovery and creativity—an active state.

In keeping with this active state, and the fluidity and pluralism inherent in feminism, museums can adopt institution-wide feminist models that guide the institution through its own recreation and discovery. Facets of a feminist model of museum management to guide museums into the future are already present in the efforts of institutions that expand their programming to accommodate differences of identity in visitors. Though the primary focus of this programming is still art, the institution recognizes that people learn differently, and that older exhibitionary models do not engage all audiences. Education and programming are only two facets of museum management. A curatorial department influenced by a feminist model of museum management would blur departmental distinctions, encourage collaboration, require continuing and diverse education, promote scholarship, increase transparency, and foster education.

Departmental distinctions perpetuate the arbitrary separations of objects, as Hein advised against in her essay on redressing the museum. As mentioned previously, a tapestry and a painting are quite different objects in a traditional museum, even if they are from the same time-period and region. Their dissimilarity is related to the history of the 
two mediums and the hierarchy that separates fine art from craft. Since the intention of a feminist model of museum management is to neutralize power structures and eliminate hierarchies, the art/craft dualism should be rendered irrelevant. A singular decorative arts curator only supports the hierarchy. If art is permitted several curators related to time periods, styles, and mediums (Renaissance, Modern, Contemporary, painting, photography) then so should craft. Alternately, craft mediums should be part of the expertise of curators who specialize in time periods and styles, as generally in the history of art one medium was utilized simultaneous to the other: tapestries with paintings; crocheted room installations with large, steel sculpture.

Collaborations would also blur these distinctions and collapse hierarchies. These collaborations can occur among curators in a singular exhibition, so that even the privilege of time is not sanctioned over the ingenuity in more contemporary art. Curators and administrators could be encouraged to partner with other scholars either in art history or in other disciplines, merging the study of art with the study of music, or physics even. Most institutions are situated in cities with major research universities that produce a wealth of scholarship and knowledge on a variety of topics that are also relevant to art making. Being $\&$ Making would have greatly benefited by a panel discussion on identity across research disciplines. I could have invited professors of art history, women and gender studies, and economics, for example, whose research aligns with the topic of identity. Not only could this type of programming attract new visitors, but it also unveils mysteries of other disciplines and demonstrates the universality of the topic.

To require continuing and diverse education while promoting scholarship is to concede that knowledge itself is fluid. In order to continue to, as Oberhardt says, resist 
"odious and dominant world views and creating fresh meanings, identities and fairer ways of life" curators and administrators must keep their perspectives fresh by staying current on new trends in scholarship and administration. Since curators and administrators are educators, it is often difficult to find the motivation and opportunity (and perhaps humility) to continue their own education and scholarship. The institution should subsidize, and even require, continued education and scholarship by paying for audited classes and allotting a specific percentage of work-time to scholarship and extrainstitutional publishing and/or presenting to ensure that museum professionals remain current and relevant. As a result, a senior curator with a career spanning several decades in one institution is not fixed on trends in scholarship contemporaneous to her time in graduate school.

By continuing a presence in educational institutions, museum administrators are expanding their knowledge base while fostering education through their relationship with educational institutions. These relationships can lead to more internship opportunities, more collaborations between museums, and students and professors in the form of lectures, museum visits, and even exhibition planning. This supports the education institution as well by enhancing their offerings for students through their partnership with the museum. This produces community-wide benefits, and expands the scope of the museum even further making it more accessible to more people while it keeps the museum informed of the needs and expectations of its community. 


\section{CONCLUSION}

Oberhardt is recommending a movement toward Derrida's free play. The bigger picture, and the continued deconstruction of prevailing frames is in the active tense that Pollock and Hein reference in their use of verbs: "differencing" and "redressing." Even my own use of "being" and "making" are efforts to allow the flexibility of play. It reinforces the notion that just because something was does not mean that it will always be. There is freedom in that play, and in the deconstruction of the frameworks that attempt to wrangle it. Investigations of identity in the last part of the twentieth century, backed by poststructuralist and feminist ideologies, influenced the paradigm shift in museum management that resulted in a more fluid, more inclusive adaptation of museum utility. In efforts to expand their visitor base, museums have made these identity-based investigations part of their operations.

The goal is not to do away with the art historical canon, but as Hein says, to enlarge it, or as Pollock says, to difference it. Museums are meaning makers, their narrative becomes part of broad cultural truths, phenomena that is integrated into the individual identities of the public that experiences it. Those meanings can carry significant power, and send specific messages relating to identity, including which individuals are valuable, and which individuals are not worthy of representation in the art or people seen in their institution. Visitor evaluations aim to increase attendance through a change in standards for their programming; broadening their offerings to appeal to a wider variety of visitors. These evaluations began simultaneously with wider cultural 
investigations of identity, inspired directly from the feminist and civil rights movements of the decades before. The pluralism inherent in feminism allowed for these developments, and it presents an ideal framework for the progression of museum reform in the future. 


\title{
BEING \& MAKING: ARTISTS INVESTIGATING IDENTITY
}

\author{
The Speed Art Museum, Louisville, KY
}

July 2-November 6, 2011

Curated by Sarah G. Cassidy

\section{CURATORIAL INTENT}

This thesis exhibition is a result of three years of graduate study on issues of identity in contemporary art. For my personal interest, this topic seemed absolutely essential. For the purposes of the Speed Art Museum, an exhibition focusing on identity has not been in the exhibition schedule for several years. There are many reasons why identity warrants further discussion at this moment in history. Popular culture gives particular attention to the topic, as does current legislation. Rights for gay marriage, the repeal of "Don't Ask Don't Tell," attacks on Roe v. Wade, the rise of the Tea Party movement and the religious right wing, the prominence of women and non-white men in high levels of government, coupled with Lady Gaga's "Born this Way" movement, as well as her transgendered appearance on the 2011 MTV Video Music Awards, are all related to issues of identity and one or more of these occurrences reach the people of this country through news networks, newspapers, magazines, internet sites, and word of mouth. Rarely, however, are the sources of these topics discussed. Rarely are these issues broken down to their most essential elements: who we are, what we do, and who tells us who we are and what we do-identity and power. 
The Speed Art Museum sits on the campus of the University of Louisville. Because of this, its demographic is highly concentrated by graduate and undergraduate students. University of Louisville students enjoy free admission to the museum, and professors often assign visits as part of research and writing, not only for art history classes, but for many other disciplines as well. In my internship with Suzanne Weaver, I have learned that it is one of the primary goals of every exhibition to engage the student community of the university. Particularly for Weaver, it is important that each exhibition contain issues and corresponding interpretation material that lead students into deeper inquiry on themes of contemporary art. This was a large part of my intentions for Being $\&$ Making. I felt that it was a significant and relevant theme for the student community, covering philosophy, ethics, music, political science, literature, economics, applied sciences, and even in popular culture disciplines. Even in my own graduate level economics class in the department of urban and public affairs, we are reading a recently published book entitled "Identity Economics: How Our Identities Shape Our Work, Wages, and Well-Being." ${ }^{109}$ Truly, identity is a prominent theme in academia. For many students, the exhibition is a continuation of topics discussed in their classes. For other students, this will be the first of many times that this topic enters into their academic discourse.

Through my graduate studies, I am aware of the history of controversy surrounding exhibitions on identity. ${ }^{110}$ Most of these mistakes were made in setting where the discussion was new, controversial, and vulnerable to the harsh criticism often

\footnotetext{
${ }^{109}$ George A. Akerlof and Rachel E. Kranton, Identity economics: how our identities shape our work, wages, and well-being, (Princeton: Princeton University Press, 2010).

${ }^{110}$ Vanessa Faye Johnson's master's thesis entitled Difference as Identity in "The Other Story" And The 1993 Whitney Biennial (University of Louisville, 2009) provides a wonderful historiographic account of two of these watershed exhibitions.
} 
present in times of transition away from past traditions. These exhibitions tried to be exhaustive and were decidedly not so, or tried to be representative but were instead ghettoizing, and some were simply trying to present a controversial perspective and were received with harsh resistance. Many of these exhibitions showed large amounts of artists, contained a variety of themes, and some of the leading and most widely visited art museums in the country presented these exhibitions, such as the 1993 Whitney Biennial. For a budding curator, this history was not an easy one to approach. It has been over two decades, however, since major art museum exhibitions began presenting exhibitions on identity. In this time, the waters for this topic have grown gentler and significantly easier to navigate. It is with gratitude to and knowledge of this history, that I felt confident in my ability to present this exhibition with sensitivity, care, and respect.

I was limited to selecting works from the Speed Art Museum's permanent collection. This challenge (or privilege, as it felt to me) proved itself relevant to my curatorial practice on many levels. Working with a permanent collection and with the preparatory team was in itself a valuable experience. Access to these artists' works for my own exhibition was, for lack of a better term, a dream come true. Also, in my experience as an intern at the Speed with Weaver, I learned that it is the responsibility of the curators to continue research and inquiry into the permanent collection. This involves exhibiting the works in varying ways as to maintain relevance and attention to accessioned objects. Being \& Making resulted in the manifestation of this practice, as it united the decisions of the last two decades of curators and directors at the museum.

The previous curator of contemporary art, Julian Robson, incorporated a focus on identity in his collection plan in 2000 and accessioned many of the works in this 
exhibition into the collection, such as those of the artists Dinh Q. Lê, Carrie Mae Weems, and Alfredo Jaar. Prior to this, the Museum's previous director, Peter Morrin, with his finger to the pulse of contemporary culture just as the life-blood of the significance of identity was beginning to flow, also made several wise accession decisions which enabled the acquisition of works by such artists as Kiki Smith, Lorna Simpson and Barbara Kruger. These artists have been on the front lines of this new identity frontier since the 1980s and 1990s, their work often appearing as textbook examples of this new development in contemporary art. Suzanne Weaver, the Museum's current curator of contemporary art, continued this tradition not only by continuing to collect work by nationally and internationally recognized artists working in themes of identity, but also by accessioning works by promising local artists, honing a focus on identity even closer to the immediate community.

It is with this strong curatorial history that this exhibition was able to represent this significant theme in contemporary art. I regret that my favorite work in the Museum's collection was not included in this exhibition-Yinka Shonibare's Three Graces created in 2001. This work is resting from its extensive travelling with the exhibition "Pattern ID" organized by the Akron Art Museum in Ohio. With the exception of Three Graces this exhibition contains the work in the collection about which I am most excited and passionate. It is no coincidence that these works are all linked by the theme that has been so prominent in my graduate research. These works have never before been grouped together at the Museum, and I was excited to be able to do that, and to show the strength of the museum's contemporary art collection. 


\section{EXHIBITION INTRODUCTION TEXT}

Being \& Making: Artists Investigating Identity is a group exhibition that focuses on the exploration of identity in contemporary art. Identity is often understood as a way of viewing oneself and one's environment; how we see the world and how we are perceived by others. The meaning of identity has changed throughout time, though it remains one of the fundamental points from which art history is studied. Nearly every aspect of our existence contributes to the formation of identity: gender, sexuality, class, religion, politics, ethnicity, skin color, occupation, education, culture, nationhood, and our bodies' conditions and experiences.

In the last quarter of the twentieth century, theories of identity emerged that resulted in a revolutionary way of understanding the subject. These theories challenged the prevailing view that the individual was the locus of identity, and instead drew attention to the significance of external social forces in determining identities. Identity was understood not to be natural or self-evident, but rather relational-dependent upon communities, environments, and ideologies. Most importantly, identity was deemed to be a fluid construction, which suggests that it is not fixed and can be redefined. The question can thus be considered to include not only what shapes identity, but also who. This became a question of power and power relations, and an important source of political and self-empowerment in civil rights movements across the globe. Identity can be claimed or rejected, taken on or off in a kind of performance that fluctuates as environments and individuals change. 
Art-making historically parallels social, philosophical, and theoretical developments, as is the case with concepts of identity. The variety of artistic and thematic approaches highlighted in Being \& Making offers a glimpse into the complexities of identity, and the manifestation of its fluidity. For each artist, and each viewer, definitions of identity are vast, cumulative and dynamic. The identities that the artists present are a conduit for connecting with viewers' own identities and a platform on which to build further discussion, contributing to the accumulation of information and experience that shapes individuals and communities. This type of interpersonal exchange can inspire powerful connections that nurture tolerance, acceptance, sympathy, empathy, and individual freedoms. 


\section{OBJECT LABELS \& IMAGES}

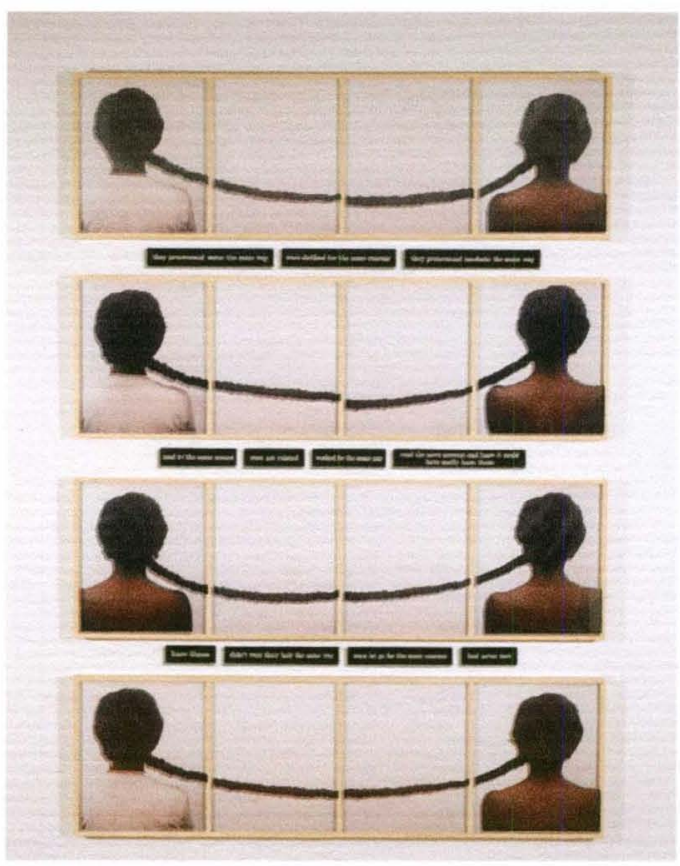

Figure 1

Same, 1991

16 color Polaroids in four frames with 11 plastic plaques

$1181 / 2 \times 821 / 4$ x $17 / 8$ in. (301 x 208.9 × $4.8 \mathrm{~cm}$.) installed

\section{LORNA SIMPSON}

(American, born 1960)

A pioneer in conceptual photography, Lorna Simpson became well-known in the mid1980s for her large-scale photography and text based works that confront and challenge views of identity based in concepts of gender, culture, history and memory. With the African American woman as the central focus, Simpson uses the figure and body to explore how culture, language and speech influence interactions, relationships and experiences in contemporary multi-racial America. In Same, the figures are turned away 
from the viewer and joined by their hair. The subject becomes a symbol for African American women while their concealed face emphasizes the negation of identity prevalent in racism. Plaques below the photographs with inscribed text confront the viewer with evidence of a common experience that is often not considered when relationships are blinded by prejudice.

Gift of the New Art Collectors 1991.22.2 a-e 


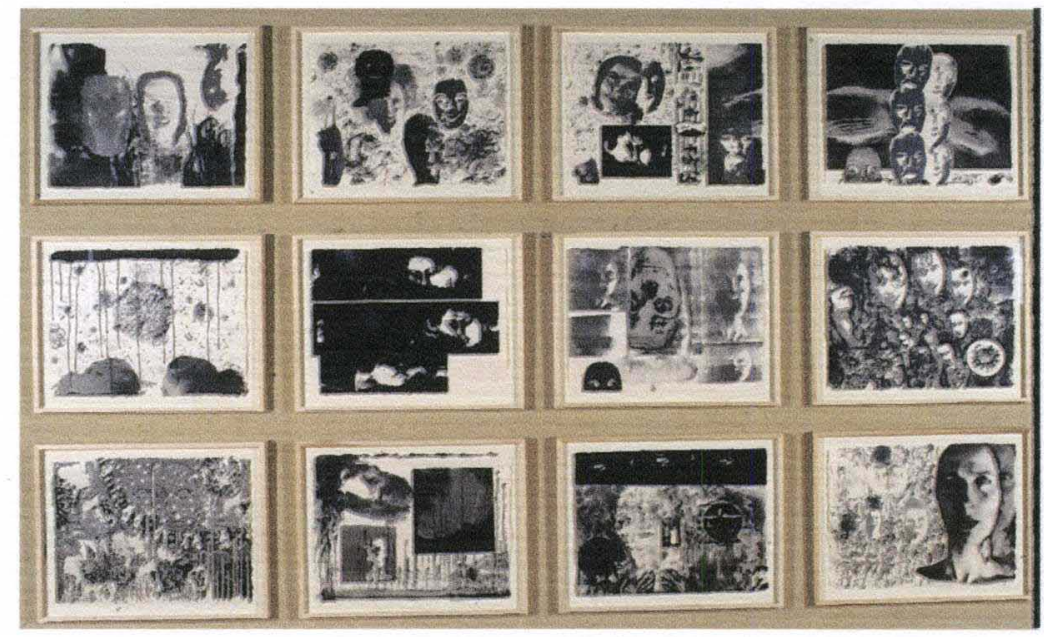

Figure 2

Banshee Pearls, 1991

4 color lithographs on 12 sheets of Torinko paper

$221 / 2 \times 30$ in. $(57.2 \times 76.2 \mathrm{~cm}$. $)$

KIKI SMITH

(American, born 1954)

In Banshee Pearls, Smith combines images of her face and hair with round symbols traditionally associated with the female body. The many haunting images suggest the relationship between body and soul. Influenced by her Catholic and Irish heritage she alludes to the banshee spirits of Gaelic folklore, whose wails signaled an imminent death in the family. Fascinated with death since childhood, young Kiki was often called a banshee by her father, the abstract sculptor Tony Smith. In a reversal of their traditionally negative association, Smith calls upon the banshees to inspire her. The artist says that the Banshee Pearls were her first foray into self-portraiture; they created, she says, "a backdoor into using myself as a subject." Smith toys with the idea of representation, as the images range from blurred and unrecognizable to photographically accurate. In doing this she interprets female personae and feminine symbols as sources of life, death, beauty 
and imaginative power.

Gift of Reverend and Mrs. Alfred R. Shands III 1992.3.1-.12 


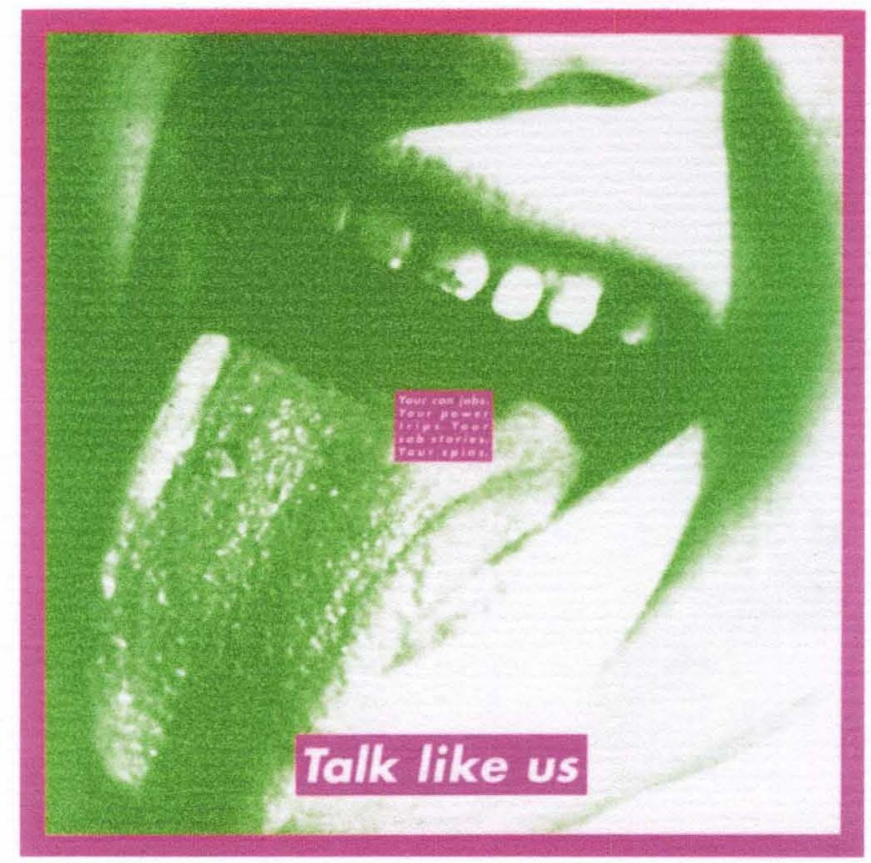

Figure 3

Untitled (Talk Like Us), 1994

Photographic screenprint on Plexiglass

$55 \times 55 \times 1 / 4$ in. $(139.7 \times 139.7 \times 0.6 \mathrm{~cm}$.)

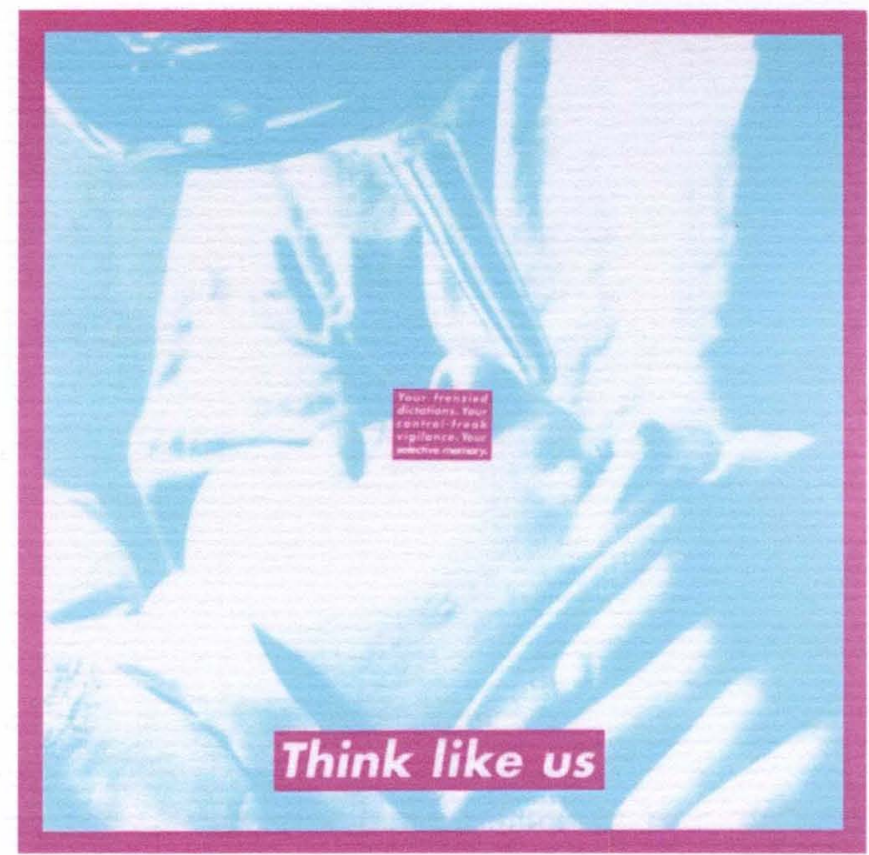

Figure 4

Untitled (Think Like Us), 1994

Photographic silkscreen / plexiglass

$55 \times 55 \times 1 / 4$ in. $(139.7 \times 139.7 \times 0.6 \mathrm{~cm}$. $)$ 
BARBARA KRUGER

(American, born 1945)

From her early career as a designer and photo editor for Conde Nast publications, Kruger has developed a striking style of juxtaposing images from popular media with slogan-like texts. In her work, images of people are overprinted with phrases that are both declarative and accusative in tone. The use of the words "us" and "your" create uncertainty in the viewer as to whose voice is actually represented. The demands in the slogans suggest that the one dictating the command holds power over the one receiving the command. This power is unfair, as evidenced by the small text in the center. These power struggles are prominent in patriarchal, capitalist cultures and are often manifested in advertisements that reinforce systems of power and manipulate views of the world and of individuals. In essence, Kruger is using the same advertising techniques to expose and critique the function of that power.

Gift of Mrs. Hattie Bishop Speed, by exchange 1994.3.1-.2 


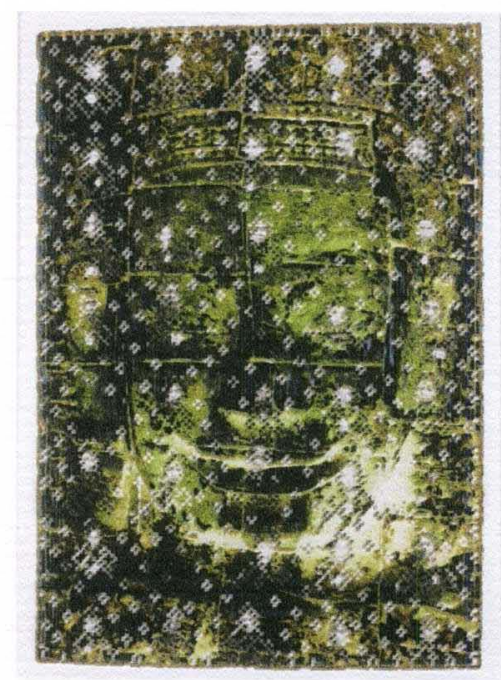

Figure 5

Untitled \#12, 1999

C-print, linen tape

$581 / 8 \times 40$ in. $(147.6 \times 101.6 \mathrm{~cm}$.)

$661 / 2 \times 461 / 2 \times 3$ in. (168.9 x $118.1 \times 7.6 \mathrm{~cm}$.) (frame)

DINH Q. LE

(American, born Vietnam, born 1968)

Dinh Q. Lê's meticulous artistic process involves slicing multiple photographs into thin strips and then weaving them together into a single work. In this work he focuses on two major events in Cambodian history: the building and later abandonment of hundreds of temples during the Angkor periods (ninth to twelfth centuries) and the genocide committed by the Khmer Rouge between 1975 and 1978 under the dictatorship of Pol Pot. One situation marks the erosion of sacred cultural architecture and the other marks the near destruction of entire cultures. By combining the two, the artist collapses the distance between the religious monuments and social abuses that were committed. As a result, his work stands in remembrance of Cambodian people and the nation's history.

Gift of the New Art Collectors 2000.14.1 


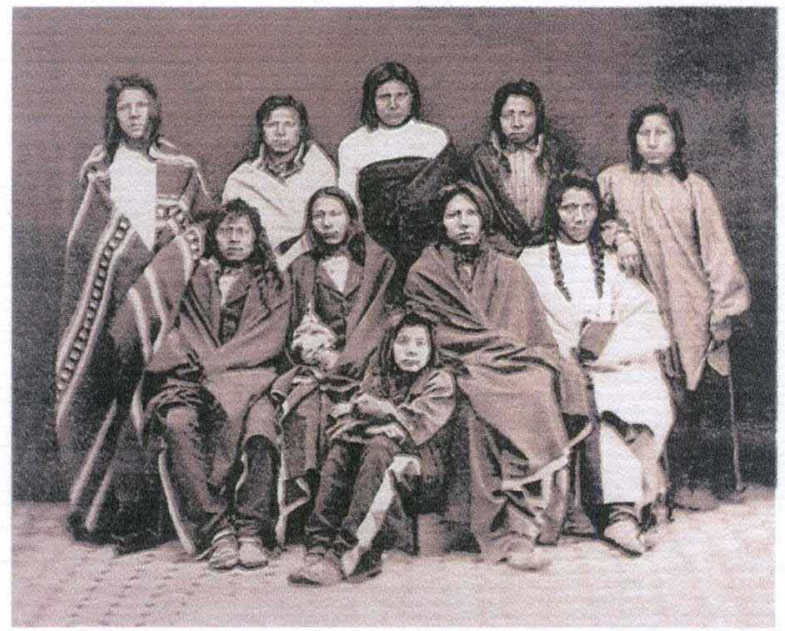

Figure 6

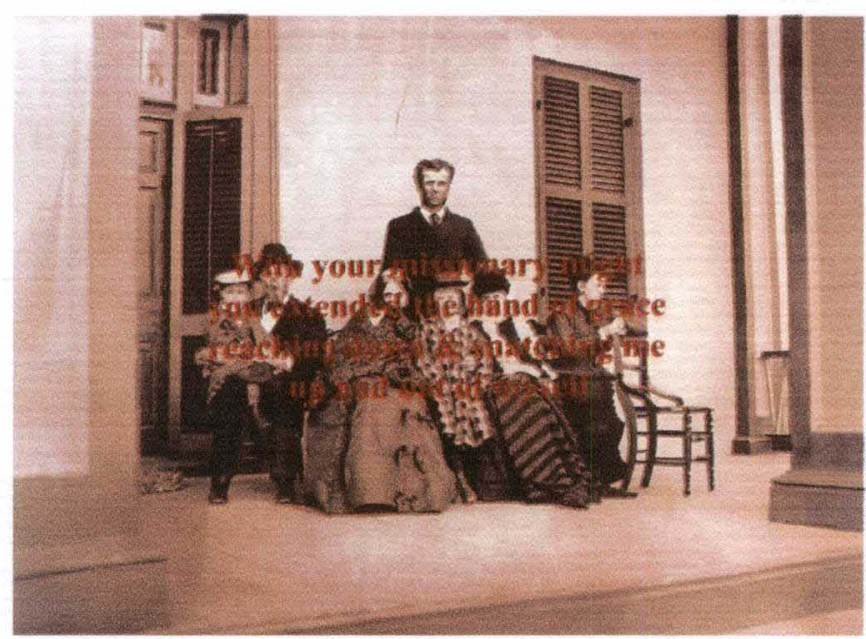

Figure 7

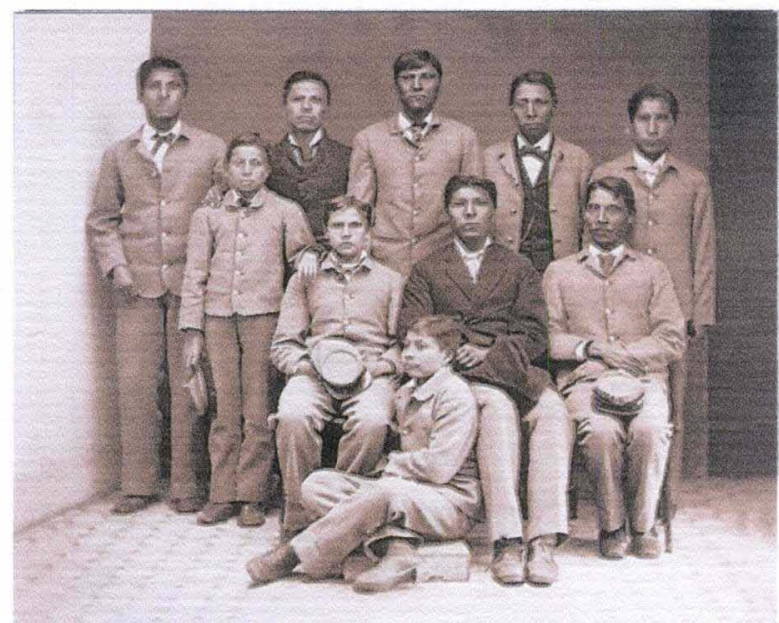

Figure 8 
The Armstrong Triptych, 2000

Ink on canvas, three parts

$68 \times 2463 / 4 \times 11 / 2$ in. $(172.7 \times 626.7 \times 3.8 \mathrm{~cm}$.) (installed)

$591 / 8 \times 723 / 8 \times 11 / 2$ in. $(150.2 \times 183.8 \times 3.8 \mathrm{~cm}$.) (panel a)

$68 \times 92 \times 11 / 2$ in. $(172.7 \times 233.7 \times 3.8 \mathrm{~cm}).($ panel b)

$591 / 8 \times 723 / 8 \times 11 / 2$ in. $(150.2 \times 183.8 \times 3.8 \mathrm{~cm}$.) (panel c)

\section{CARRIE MAE WEEMS}

(American, born 1953)

The source of the two exterior images is an album of photographs by Frances Benjamin Johnston (1864-1952) of the Hampton Normal and Agricultural Institute. Founded in Virginia by Union General Samuel Chapman Armstrong shortly after the Civil War, the institute provided education to African and Native Americans in trades and academic subjects. The two side panels show a group of Native Americans before and after their schooling, while the central panel is a portrait of Armstrong's own family, hidden behind text. This juxtaposition of word and image becomes a subversive opposition to the history of individual and cultural identity that has been altered or abolished by ethnocentric power posing as class assimilation and education.

Gift of the New Art Collectors 2001.9 a-c 


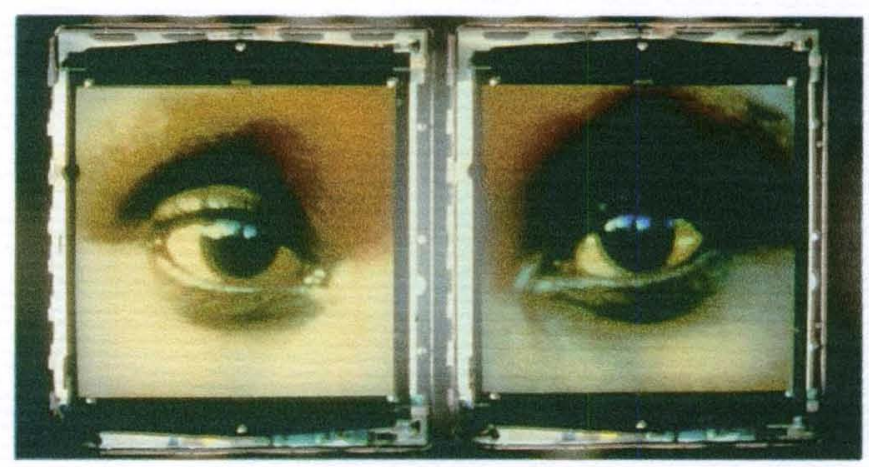

Figure 9

The Eyes of Gutete Emerita, 1996

Two quad-vision light-boxes, two transparencies, two masks, synchronizing cable $251 / 2 \times 463 / 4 \times 51 / 4$ in. $(64.8 \times 118.7 \times 13.3 \mathrm{~cm}$.) (installed)

\section{ALFREDO JAAR}

(Chilean, born 1956)

Alfredo Jaar visited Rwanda shortly after the 1994 genocide to photograph the atrocities of the massacres where nearly one million people were killed by Hutu death squads.

While visiting the Ntarama Church in Kigali he met Gutete Emerita and her daughter, who miraculously survived the slaughter that had taken place at the site only four months earlier where she saw her husband and sons murdered. In omitting the images of the bodies and choosing instead to describe the massacre with text, Jaar prevents the numbing effect that these gruesome images evoke. Instead, the victims are given an identity through the use of their names and in the testimony of Gutete Emerita. Her eyes become a living monument to the experiences of the Rwandan people. Jaar's position as an artist allows him to communicate the terrors of oppressed cultures by educating people of these atrocities. He believes that museums and universities are "the last place where you are still free to dream of a better world."

Purchased with funds from the New Art Collectors and the Alice Speed Stoll Accessions Trust $2003.9 \mathrm{a}-\mathrm{g}$ 


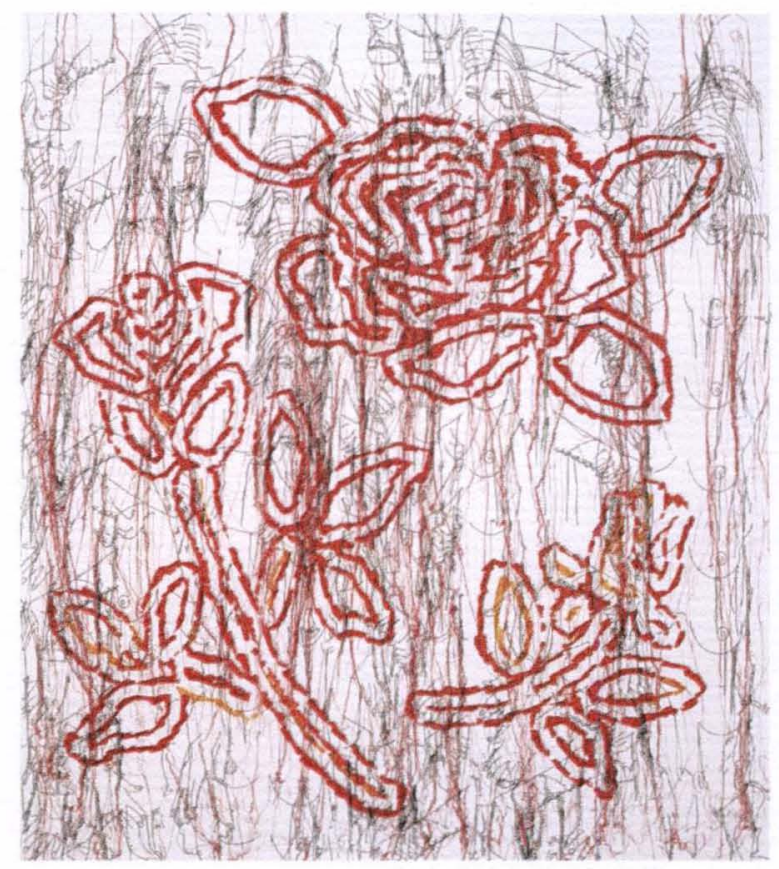

Figure 10

The Big Red Rose-RFGA, 2004

Acrylic, embroidery, and gel medium on canvas

$72 \times 64 \times 11 / 2$ in. $(182.9 \times 162.6 \times 3.8 \mathrm{~cm}$.)

GHADA AMER

(Egyptian, born 1963)

Ghada Amer describes herself as primarily a painter, though her work boldly pushes the boundaries of painting. Recognizing that the tradition of painting is male-dominated, Amer challenges this history by incorporating embroidery, a technique associated with women. In The Big Red Rose, the embroidered lines and the hanging thread, from a distance, form marks reminiscent of Abstract Expressionism. Upon closer inspection the marks reveal themselves as images of naked women amidst the image of a rose, a symbol of love and fertility. The resemblance of the painting to Abstract Expressionism is particularly fitting in this feminist critique because the art movement was infamously dominated by men and often described with adjectives also used to express stereotypical masculinity such as tough, aggressive, and active. She has been quoted saying, 
"Aesthetics alone are not enough for me and a message alone is just propaganda." The piece combines the two choices, the aestheticism of Abstract Expressionism and a provocative celebration of female sexuality and power.

Purchased with funds from the New Art Collectors and the Alice Speed Stoll Accessions Trust 2004.9.1 


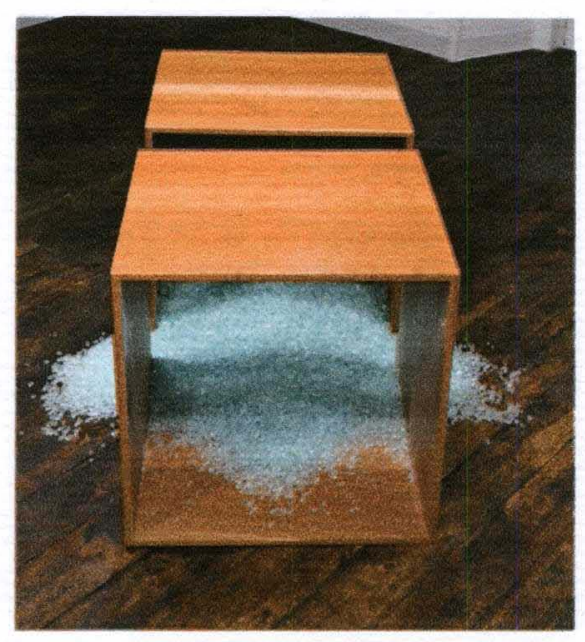

Figure 11

Crouch, 2008

Flawed cherry and shattered tempered glass

$24 \times 24 \times 22$ in. $(61 \times 61 \times 55.9 \mathrm{~cm}$.) (each piece)

CHRIS RADTKE

(American, born 1946)

They seem huge, they seem insignificant.

They seem familiar, they seem disconcerting.

They seem simple, they seem complicated.

They have sexual undertones.

They are self portraits. Some you can see through.

They are space. They are [my] personal space.

This installation is part of a series of works that act as metaphors for the body and reference the artist's immediate personal space. Radtke's work is informed by postminimalist artistic practices, combining minimalist aesthetic and conceptual ideologies. From the "Notes on Self" series Crouch is made according to the artist's body dimensions. Her body can fit inside the sculpture. The weight of the shattered tempered glass is the same as her own body weight. Both physically and psychologically, the objects occupy the same space as the artist. The work becomes an abstract self portrait, and with this consideration the materials in Crouch assume new meaning. The flawed, natural wood parallels flesh. The artist describes the natural flaws as "implying healed 
wounds." The glass becomes a metaphor for the debris one amasses in life. In Radtke's work, the pure, formal aestheticism of minimalism is infused with personal narrative, attesting to the body's relationship to physical and social spaces.

Museum purchase $2010.3 \mathrm{a}-\mathrm{c}$ 
Man Spirit Mask, 1999

Photo etching; silkscreen; photo-etching with woodcut

$391 / 8 \times 791 / 2$ in. (99.4 x $201.9 \mathrm{~cm}$.) (overall)

$391 / 8 \times 261 / 2$ in. $(99.4 \times 67.3 \mathrm{~cm}).($ each)

\section{WILLIE COLE}

(American, born 1955)

Willie Cole has transformed otherwise ordinary objects such as shoes, bathroom fixtures, hair dryers and irons into prints, sculptures and installations. Linking these objects through word association, color and cultural history, his sculptures become a tribute to concepts of family, heritage, labor, and historic gender and power roles. The iron's shape and indentations mimic not only African masks, but also the ships used to carry enslaved Africans, the petals of a flower, or a home, representing social, political and cultural perspectives of the African American experience.

In Man Spirit Mask the portrait of Cole in the first panel (Man) is an altered photograph, bringing the artist's two left sides together to make his face completely symmetrical, then overlaid with markings from an electric iron, with the steam holes of the iron referencing scarification rituals. The center panel (Spirit) is the same enlarged iron reproduced in a silkscreen technique that duplicates the appearance of scorching, using lemon juice and a heat gun to create the brownish color and vaporous edges. In the right panel (Mask) the image of Cole's face is turned upside down and printed upon with a woodcut depicting an antique, wood-handled iron, the parts of the iron mimicking facial features. The triptych 
connects the man with the mask through the spirit inherent in both.

Purchased with funds from the Alice Speed Stoll Accessions Trust 2010.12 a-c 


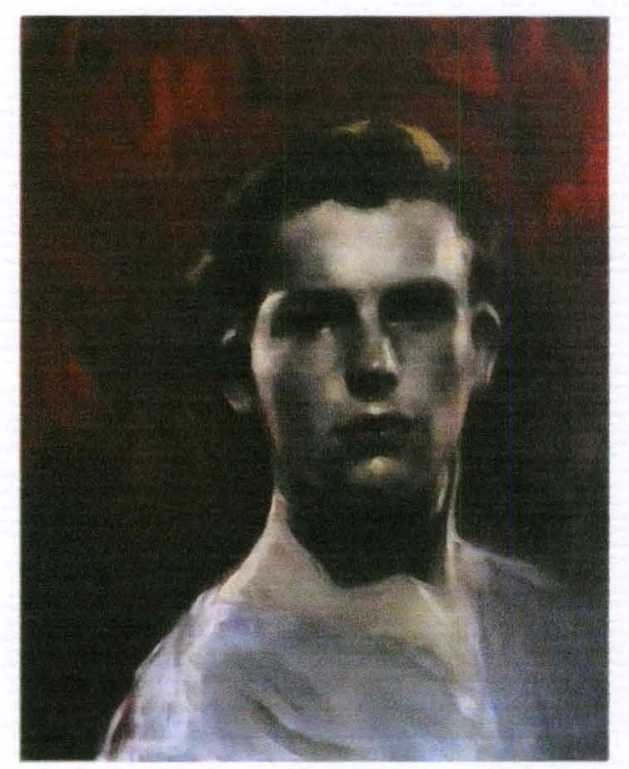

Figure 12

Untitled, 2010

Oil on canvas

$16 \times 13$ in. $(40.6 \times 33 \mathrm{~cm}$.)

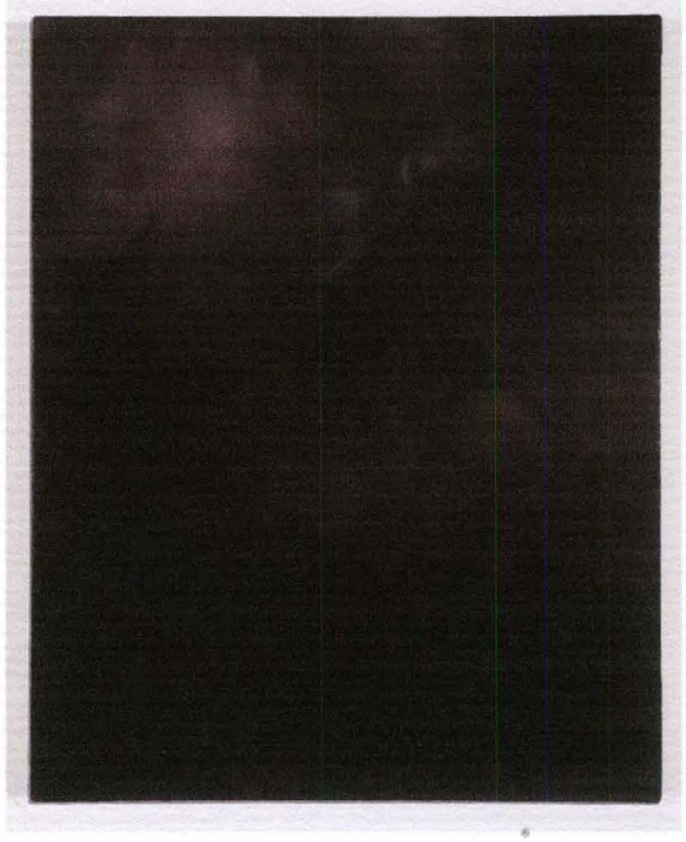

Figure 13

Untitled, 2004

Oil on canvas

$20 \times 16$ in. $(50.8 \times 40.6 \mathrm{~cm}$.) 


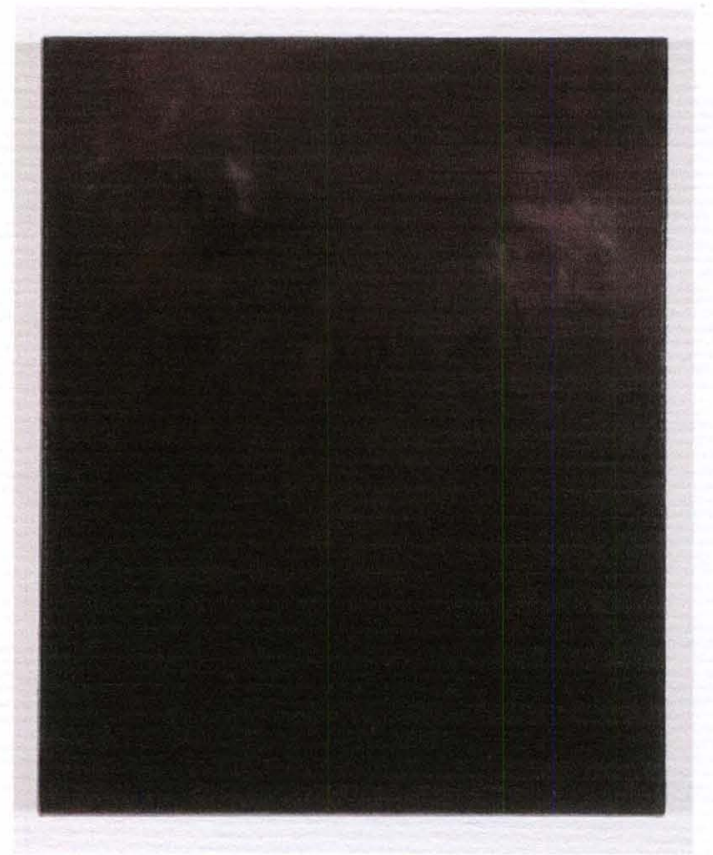

Figure 14

\section{Untitled, 2004}

Oil on canvas

$20 \times 16$ in. $(50.8 \times 40.6 \mathrm{~cm}$.)

PAUL P.

(Canadian, born 1977)

Known only by his (presumed) first name and the letter "P" this young Canadian painter is part of a Western resurgence of realistic portrait painting. Though his romantic style is reminiscent of late nineteenth century American and European painting, the images depict young pornographic models from the 1960s through the 1980s. His backgrounds often evoke, if not directly utilize, the psychologically charged ones of James McNeill Whistler. Whistler's friend, the poet and flamboyant dandy, Count de Montesquiou is also often cited as inspiration for the work, as P captures the beauty, mystery, and eccentricity of fin-de-siècle dandy culture. P's paintings remove the explicit details of the original photographs and maintain a subtle eroticism accented with longing. The sense of 
longing present can be extended past sexual desire and toward nostalgia for one's youth. The bats and the boy, both dark and romantic, are symbolic of both death and rebirth.

Paul $\mathrm{P}$ is part of a generation that has not been so tragically impacted, as the generation before him, by the threat of AIDS-related deaths in the gay community. These symbols may represent the artist himself or a sexual and cultural innocence that has been disrupted, but cannot be lost.

Purchased with funds from the Alice Speed Stoll Accessions Trust 2011.1

Gift of Marc Selwyn Fine Art and 2010.22

Gift of Paul and Joan Selwyn 2010.23 


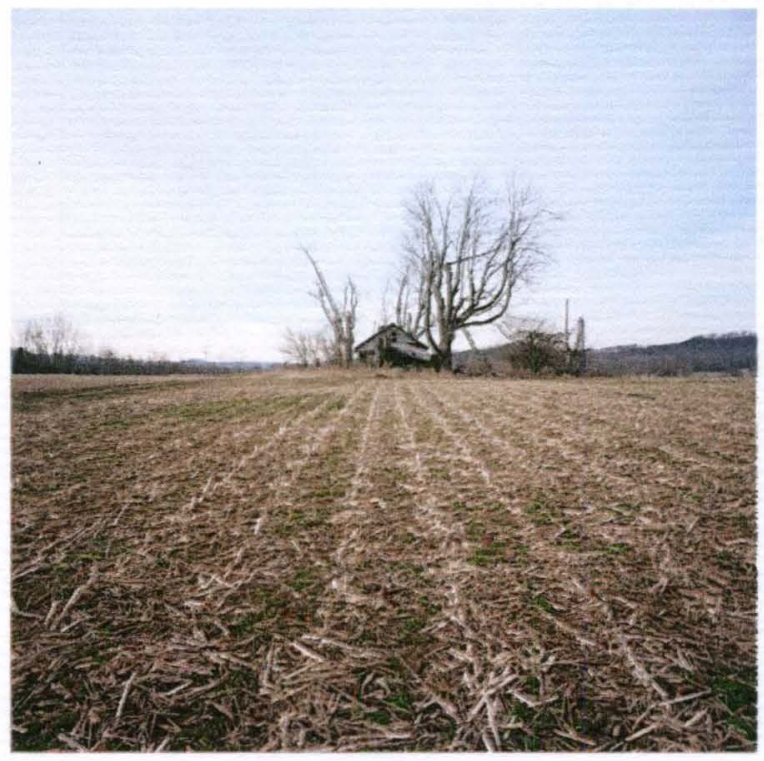

Figure 15

Indiana Farmhouse, 2009

Archival pigment print

$40 \times 40$ in. (101.6 x $101.6 \mathrm{~cm}$.)

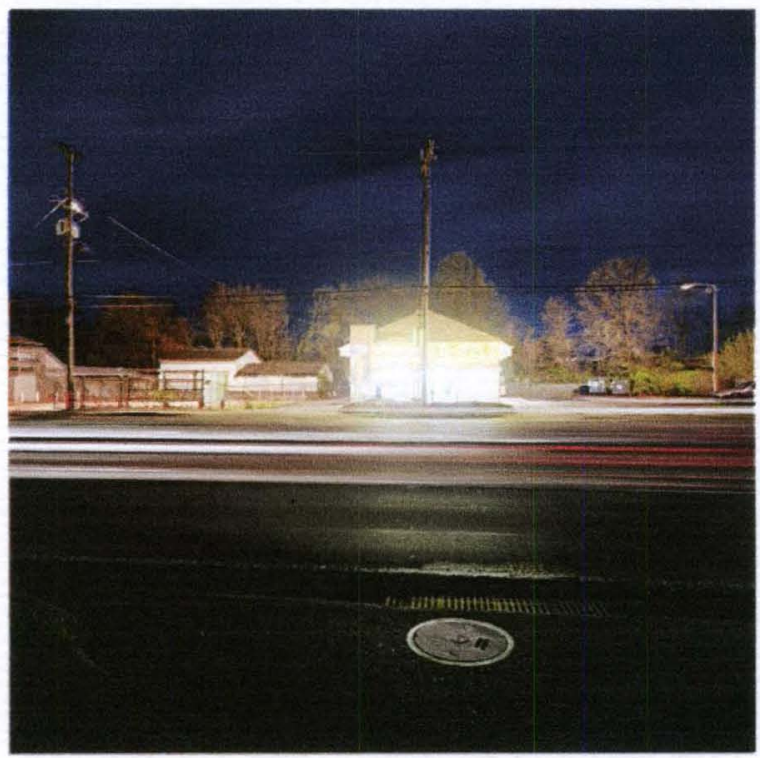

Figure 16

Cork-N-Bottle, 2009

Archival pigment print

$40 \times 40$ in. (101.6 x $101.6 \mathrm{~cm}$.)

SARAH LYON

(American, born 1978) 
A native Louisvillian, Sarah Lyon is "drawn to places that have delicate existence in regards to the elements, or to urban development and destruction." Lyon's photography adopts a snapshot aesthetic that retains the truth-revealing characteristics of post-1950s documentary photography. These two photographs, Indiana Farmhouse (2009) and Cork$N$-Bottle (2009) have a slightly eerie and haunting atmosphere. Though contrasting in subject matter, the two images share similar points-of-reference; in both, the spectator is removed by considerable distance from the structure photographed. It is unclear if these buildings are being utilized, but they seem banal, as if they are frequently passed along streets or highways. This sense of familiarity along with the distance between the spectator and the structure creates a sense of isolation, abandonment, and separation one often feels even in their own city or town.

Museum purchase 2009.4.2 and 2009.4.3 


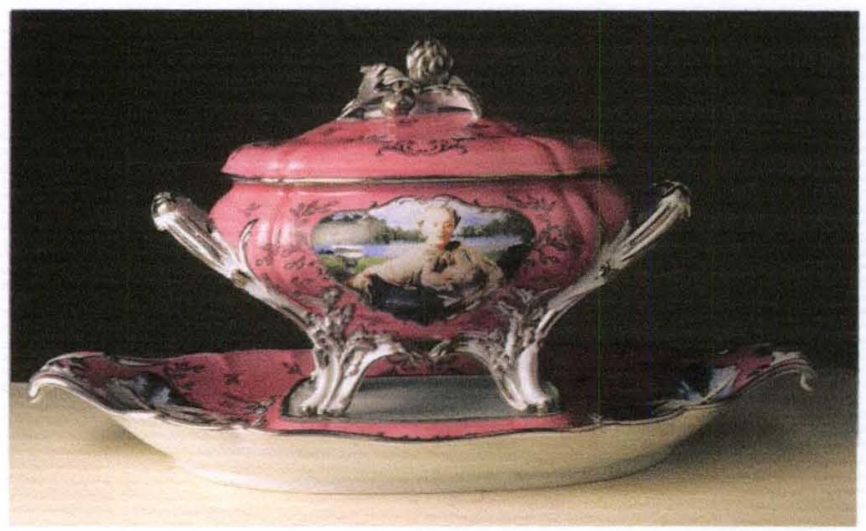

Figure 17

Madame de Pompadour Soup Tureen and Stand, 1990

Silkscreened and hand-painted porcelain

CINDY SHERMAN

(American, born 1954)

Decorated at the ANCIENNE MANUFACTURE ROYALE, Limoges, France

Cindy Sherman is known for her photographic self-portraits where she is dressed in elaborate costume or masquerade. Her body of work manifests the power of identity play, as her disguises often result in poignant commentary on various societal roles and perceptions. The tureen's design and color replicate one made in 1756 for Madame de Pompadour (1721-1764), a mistress of Louis XV's and a collector of porcelain who rose from middle class status to a favored position among the king's mistresses. Referencing the elaborate Rococo style of the time, the tureen is decorated with printed photographic images of Sherman as Madame de Pompadour. The Madame's maiden name was Poisson, French for "fish," and the interior bottom of the tureen is embellished with a still-life image that combines fish with jewels. Sherman's relaxed and sensual posture combined with the image of the fish comments on Madame de Pompadour's pursuits and accomplishments in raising her status in society through her charm and sexuality. Placed on a tureen, Sherman not only commemorates the woman's life, but also comments on 
the limitations placed on a woman's ability to gain any semblance of control over her role in society: through domesticity and sexuality sanctioned by men in power.

Museum purchase with funds from Miss Jenny L. Robbins and Mrs. Blakemore Wheeler, by exchange $1992.16 \mathrm{a}-\mathrm{c}$ 


\section{INSTALLATION IMAGES}

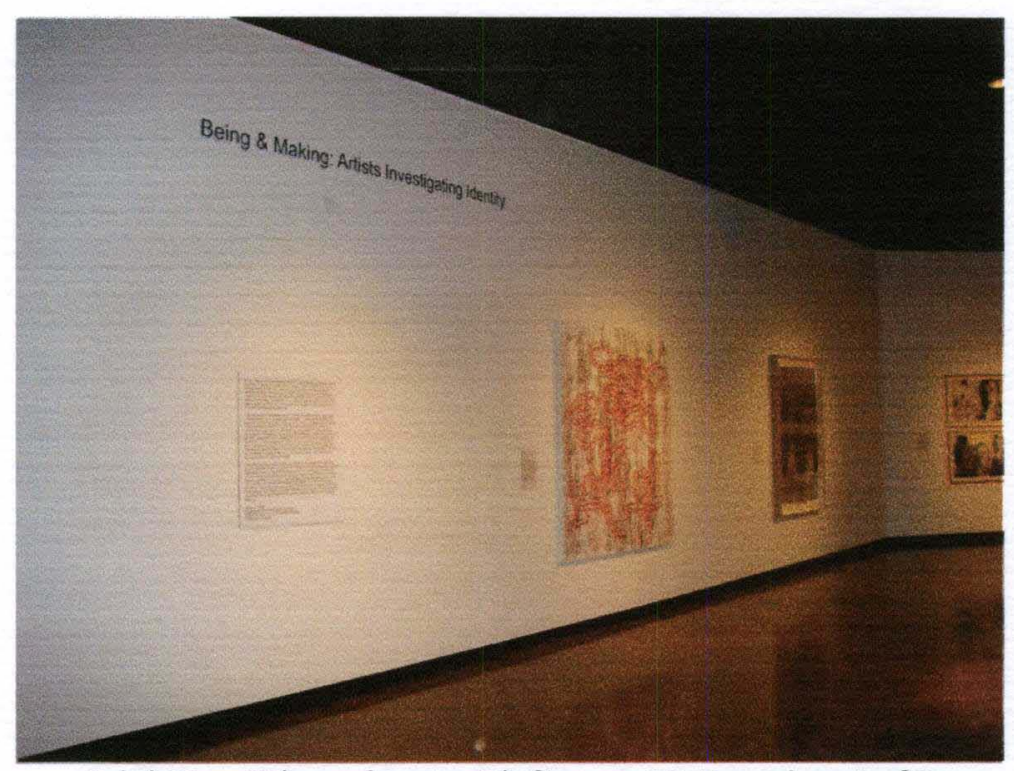

Exhibition title and text with figures 10, 5, and part of 2

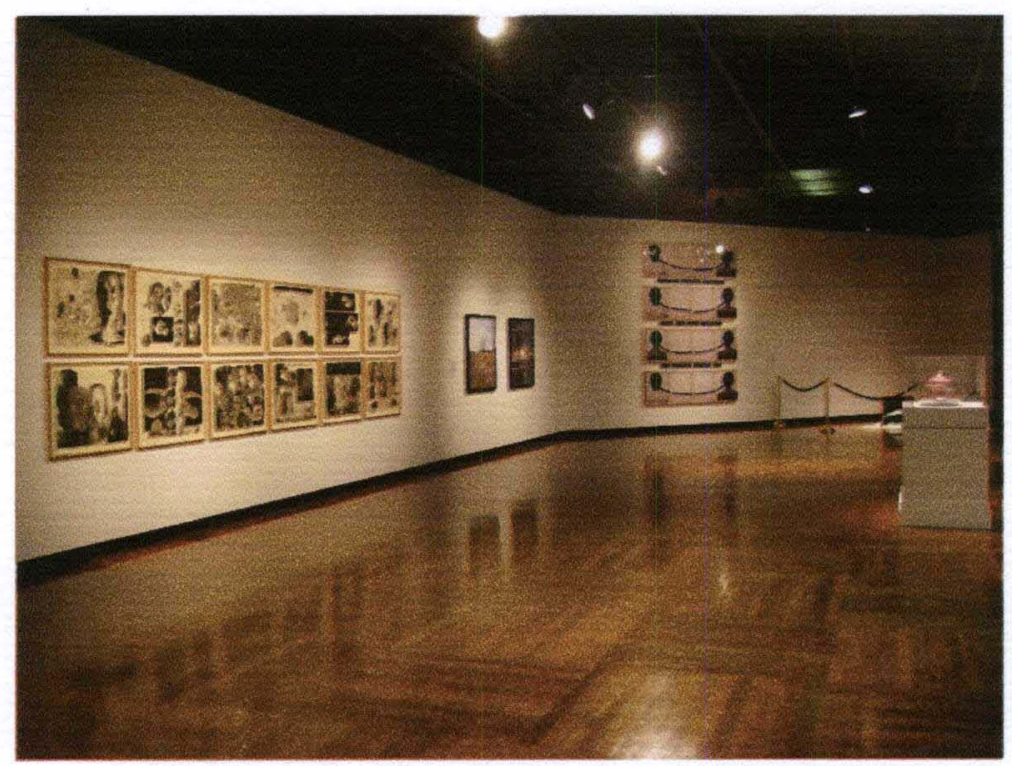

Figures 2, 15, 16, 1, 11 (floor), and 17 (vitrine) 


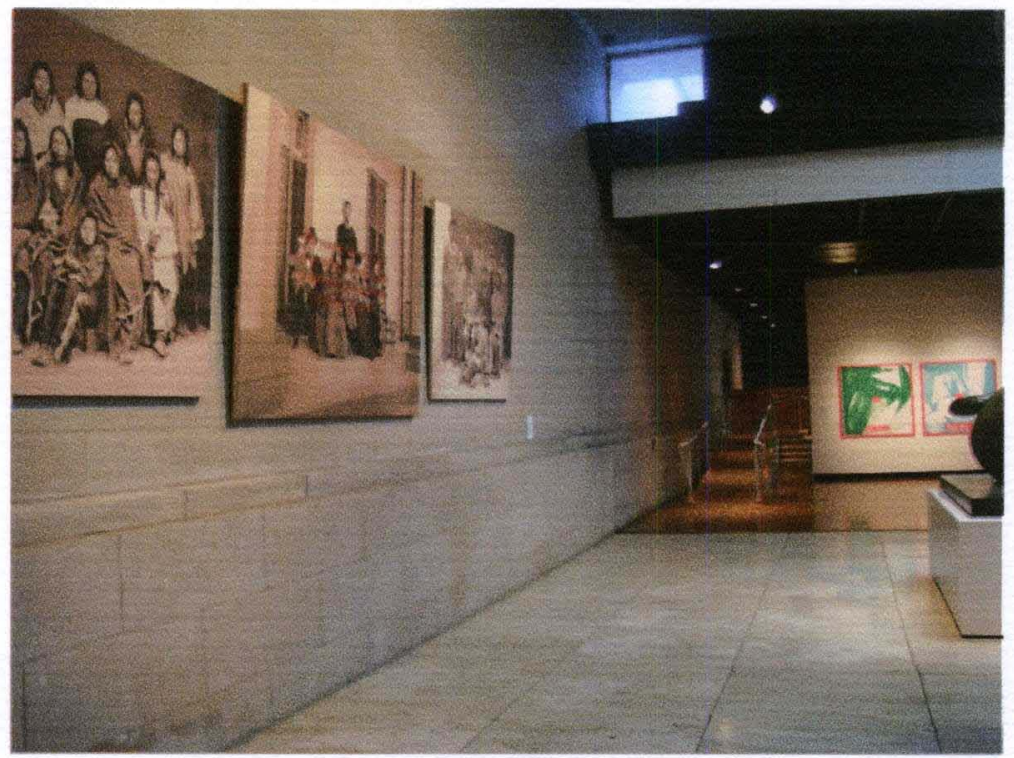

Figures $6,7,8,3$, and 4

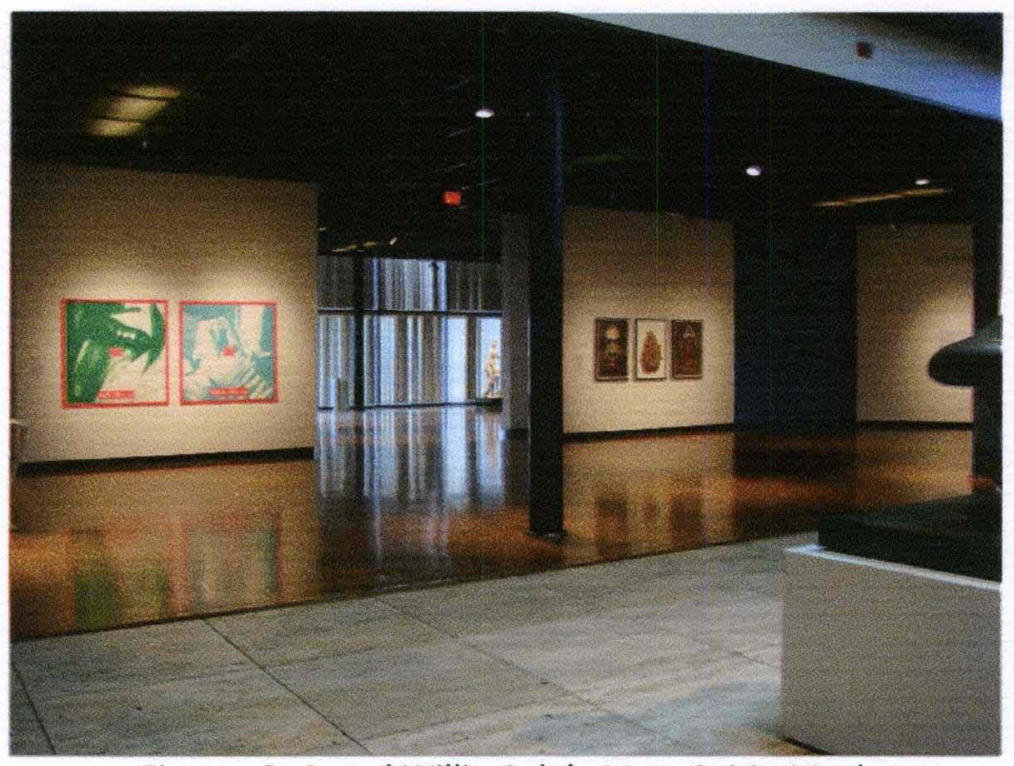

Figures 3, 4, and Willie Cole's Man, Spirit, Mask 


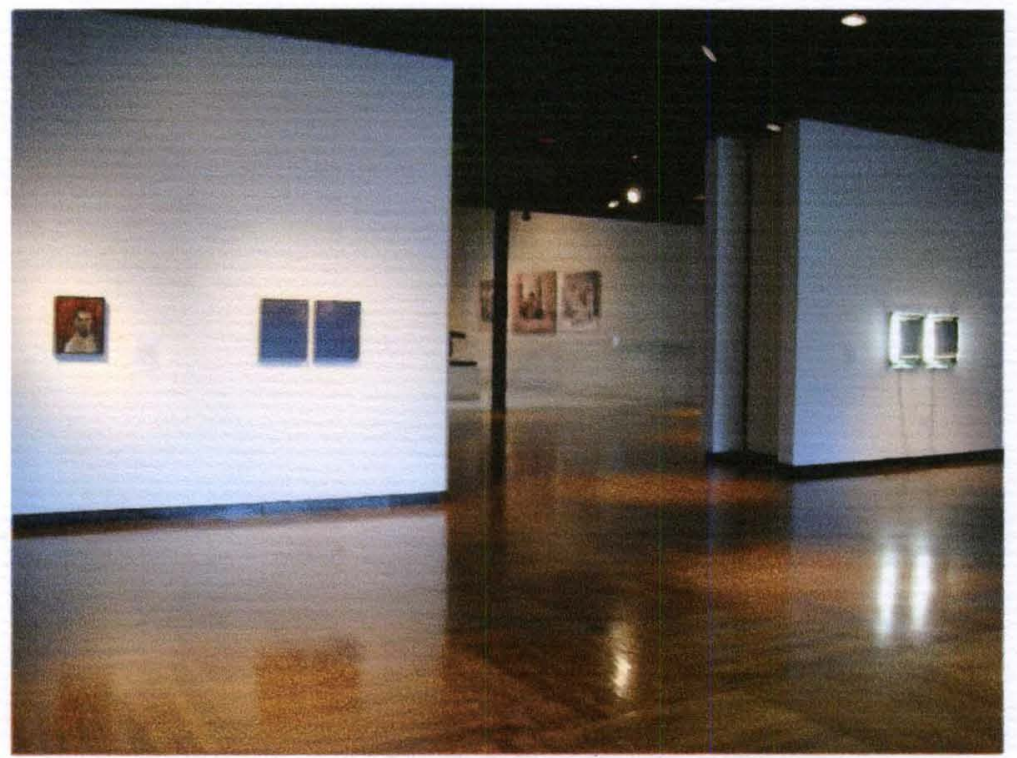

Figures $12,13,14,(6,7,8$ through walls) and 9 


\section{REFERENCES}

Akerlof, George A. and Rachel E. Kranton. Identity economics: how our identities shape our work, wages, and well-being. Princeton: Princeton University Press, 2010.

American Association of Museums. Codes of Ethics for Museums. http://www.aamus.org/museumresources/ethics/coe.cfm. Accessed October 9, 2011.

Bal, Mieke. "Telling Objects: Narrative Perspectives on Collecting." (1994) in Grasping the World: The Idea of the Museum, edited by Donald Preziosi and Claire Farango, 84-102. Aldershot, Hants, England: Ashgate, 2004.

Barthes, Roland. "Death of the Author," in Image, Music, Text, 142-148. New York: Hill and Wang, 1978.

Chave, Anna C. "The Guerrilla Girls' Reckoning." Art Journal. Vol. 70, Issue 2 (Summer 2011): 103-111.

Coffee, Kevin. "Cultural inclusion, exclusion and the formative roles of museums." Museum Management and Curatorship, 23.3 (2008): 261-279.

Coombes, Annie E. "Museums and the Formation of National and Cultural Identities" (1988) in Grasping the World: The Idea of the Museum, edited by Donald Preziosi and Claire Farango, 278-297. Aldershot, Hants, England: Ashgate, 2004.

Derrida, Jacques "Structure, Sign, and Play in the Discourse of the Human Sciences," in Writing and Difference, 278-293. Chicago: university of Chicago Press, 1978.

Duncan, Carol and Alan Wallach, "The Museum of Modern Art as Late Capitalist Ritual: An Iconographic Analysis," (1978) in Grasping the World: The Idea of the Museum, edited by Donald Preziosi and Claire Farango, 483-500. Aldershot, Hants, England: Ashgate, 2004.

Falk, John H. "An Identity-Centered Approach to Understanding Museum Learning." Curator: The Museum Journal, 49.2 (2006): 151-166.

Foucault, Michel, "What is an Author?" (1969), reprinted in The Critical Tradition, edited by David Richter, 978-988. New York: St. Martin's Press, 1989.

Hein, Hilde "Philosophical Reflections on the Museum as Canon Maker," The Journal of Arts Management, Law, and Society. 22.4 (1993): 293-309. 
Hein, Hilde S. "Redressing the Museum in Feminist Theory," Museum Management and Curatorship, 22.1 (2007): 29-42.

Hood, Marilyn "Staying Away: Why People Choose Not to Visit Museums," Museum News (April 1983): 50-57.

Johnson, Vanessa Faye. Difference as Identity in "The Other Story" and the 1993 Whitney Biennial. MA Thesis. University of Louisville, 2009.

Kelly, Lynda "Evaluation, Research and Communities of Practice: Program Evaluation in Museums," Archival Science, 4 (January 01, 2004): 45-69.

Kentucky State Data Center 2009 and 2010 reports at http://ksdc.louisville.edu/lincome.htm and http://ksdc.louisville.edu/.

Lippard, Lucy R. Mixed blessings: new art in a multicultural America. New York: Pantheon Books, 1990.

Nochlin, Linda "Why Have There Been No Great Women Artists?" (1971), Women, Art, and Power, 145-178. New York: Harper and Row, 1988.

Oberhardt, Suzanne. "Frames within Frames: The Pedagogy of the Art Museum as Cultural Artifact." Doctoral Dissertation. Pennsylvania State University, 2000. (Also published: New York and Washington: Peter Lang, 2001)

Pitman, Bonnie and Ellen Cochran Hirzy. Ignite the power of art: advancing visitor engagement in museums. Dallas: Dallas Museum of Art, 2010. Online at http://dallasmuseumofart.org/AboutUs/Frameworkforengagingwithart/index.htm

Pollock, Griselda. "Unframing the Modern: Critical Space/Public Possibility," in Museums after modernism: strategies of engagement, edited by Griselda Pollock and Joyce Zemans, 1-39. Malden, MA: Blackwell, 2007.

Pollock, Griselda. Differencing the Canon: Feminist Desire and the Writings of Art's History. New York: Routledge, 1999.

Robertson, Jean and Craig McDaniel, Themes of contemporary art: visual art after 1980. New York: Oxford University Press, 2005.

Speed Art Museum 2009990 Form, Accessed October 9, 2011, http://www.guidestar.org/FinDocuments//2009/610/444/2009-610444823060c6a5d-9.pdf

Weil, Stephen E. Making Museums Matter. Washington, D.C.: Smithsonian Institution Press, 2002. 
Yenawine, Philip. "But What Has Changed?" in Art Matters: How the Culture Wars Changed America, edited by Julie Ault, Brian Wallis, Marianne Weems, and Philip Yenawine, 8-23. New York: New York University Press, 1999.

Yenawine, Phillip. "Writing for Adult Museum Visitors." New York: Visual Understanding in Education. 2001, Accessed October 15, 2011:

http://www.vtshome.org/system/resources/0000/0212/writing for adult_mus visi tors.pdf 


\title{
CURRICULUM VITAE
}

\author{
SARAH GUADALUPE CASSIDY \\ 1928 Roanoke Ave Apt 2 - Louisville, KY 40205 \\ sarahgcassidy@yahoo.com·Phone \#: 832.567.5530
}

\section{Education}

2011

Master of Arts in Critical \& Curatorial Studies

Master of Public Administration

University of Louisville, Joint Program

$2004 \quad$ Bachelor of Fine Arts, Printmaking

Milwaukee Institute of Art \& Design

Internships, Assistantships \& Professional Experience

2011-Present Development Coordinator- Filson Historical Society, Louisville, KY

2009-2011 Research Assistantship- Speed Art Museum, Louisville, KY

2009-2011 Contracted Writer (various projects)- Contemporary Arts Museum Houston, exhibition catalogues; Speed Art Museum, Louisville, KY. member magazine

2009 Curatorial Intern- Contemporary Arts Museum Houston

2009 Intern-21C Museum, International Contemporary Art Foundation Louisville, KY

2008-2009 Curatorial Assistantship- University of Louisville

2006-2008 Gallery Coordinator- Bosque Gallery, Lone Star College, Cy-Fair, Cypress, TX 